\title{
Konut Politikalarının Fiziksel Yansımaları; Kadıköy Örneği
}

Öz

\author{
Sıddıka Filiz AYDIN GÖK ${ }^{1 *}$, Candan ÇINAR ÇITAK ${ }^{2 *}$
}

Türkiye Cumhuriyeti'nde, devlet politikaları ve sosyo-ekonomik koşullar, konut sunumunda ve yapılı çevrenin oluşmasında kemikleşmiş bir "habitus" yaratacak kadar etkili olmuştur. 1965 'te "Kat Mülkiyeti Kanunu" ile ortaya çıkan ve 80'lerde gelişen "yapsat konut sunumu", 1999 Marmara Depremi sonrası 2012'de yürürlüğe giren "Afet Riski Altındaki Alanların Dönüştürülmesi Hakkında Kanun” ile yeni bir ivme kazanmıştır.

Bu çalışmanın amacı; Türkiye Cumhuriyeti (konut) politikalarının, konutun ve kentsel dokunun oluşmasındaki etkisini göstermek ve kentsel dönüşüm kapsamında kaliteli konut yerleşimleri yaratmaya yönelik yeni ve bütüncül yaklaşımların gerekliliğini ortaya koymaktır. Araştırmada cumhuriyet döneminde etkili olan konut politikalarına göre, özellikle son 70 yılda parsel ölçeğindeki konut binasının fiziksel değişimi örnekler üzerinden incelenmiştir. Bu değişimin mahalle ve kent dokusuna fiziksel olarak nasıl yansıdığı da haritalar ve resimler yardımıyla değerlendirilmiştir.

Araştırma alanı olarak İstanbul'da "kentsel dönüşüm"ün en yoğun şekilde yaşandığı ilçe olan Kadıköy seçilmiştir. Kadıköy Belediyesi'nden temin edilen kentsel dönüşüm öncesi ve sonrası mimari ruhsat projeleri yardımıyla konut binasındaki fiziksel değişim açıkça ortaya konmuştur.

Araştırma sonucunda; İstanbul'da kentsel dönüşümle birlikte en yaygın halini alan yapsat konut sunum kültürünün, kentsel donatı alanlarının yetersiz kalmasında ve kentsel dokunun obezleşmesindeki etkisi; yıllara göre "katlar alanı katsayısı" değişimi ve "konut stoku" verileriyle desteklenerek gösterilmiştir. Mevcut konut sunum biçiminin bizi taşıyacağı bir sonraki durak, karşılaşılması muhtemel sorunlar ve çözüm önerileri Kadıköy örneğinden yola çıkarak tartışılmıştır.

Anahtar Kelimeler: Konut Politikaları, Kentsel Dönüşüm, Konut

\section{Physical Reflections of Housing Policies; A Samle of Kadıköy District}

\begin{abstract} entered into force in 2012 after the 1999 Marmara Earthquake.

\footnotetext{
${ }^{1}$ Doğuş Üniversitesi, Sanat ve Tasarım Fakültesi, Mimarlık Bölümü

${ }^{2}$ Yıldız Teknik Üniversitesi, Mimarlık Fakültesi, Mimarlık Bölümü

* Ilgili yazar/Corresponding author: sfilizgok@yahoo.com

Gönderim Tarihi / Received Date: 25.05.2020

Kabul Tarihi / Accepted Date: 15.04.2021
}

The Republic of Turkey, government policies and socio-economic conditions, is effective in forming the housing supply and built environment. This effect is enough to create an ossified "habitus". The "build-and-sell housing supply", which emerged in 1965 with the "Property Ownership Law" and developed in the 80s, gained a new momentum with the "Law on the Transformation of Areas Under Disaster Risk" that

The aim of this study is to show the effect of the policy of the Republic of Turkey on housing and urban tissue. And to reveal the necessity of new and holistic approaches for creating quality housing settlements within the scope of urban transformation. In the 
research, the physical change of the residential building on the scale of the parcel in the last 70 years, according to the Republican era housing policies, was examined through examples. How this change was reflected physically on the neighborhood and urban fabric was evaluated with the help of maps and pictures.

Kadıköy, which is the district where "urban regeneration" is experienced most intensively, was chosen as the research area. The physical change in the residence building has been clearly demonstrated with the help of "building permit projects" before and after regeneration provided by Kadıköy Municipality.

A result of the research; The effect of build-and-sell housing presentation culture, which has become the most common with urban transformation in Istanbul, on the inadequacy of urban reinforcement areas and obesity of urban tissue; It is defined by supporting the "floor area ratio" change by years and the "housing stock" data. The next stage where the current housing supply model will carry us, possible problems to be encountered and solution suggestions have been discussed based on the example of Kadıköy.

Keywords: Housing Policies, Urban Regeneration, Housing

\section{Giriş}

Türkiye'de sosyo-ekonomik koşullar ve konut politikaları birbirini sürekli besleyen bir etkileşim içindedir. Bu etkileşimin bir sonucu olarak yapılı çevrenin şekillendiğini ve değiştiğini söylemek yanlış olmayacaktır.

Cumhuriyetin ilk yıllarında sosyo-kültürel ve ekonomik koşullar gereği bireysel konut sunumu ve mülk konutun yaygın olduğunu görüyoruz. 1950 sonrası endüstrileşme politikaları ve 27 Mayıs (1960) darbesiyle birlikte köyden kente göç eden nüfusun artışı gecekondulaşmayla birlikte çok katılış̧mayı beraberinde getirmiştir. İmar afları ve 1965 Kat Mülkiyeti Kanunu'yla birlikte yap-sat konut sunum biçimi çok katlılaşmanın bir yolu olarak ortaya çıkmış ve bu iki konut sunum biçimini birbiriyle yakından ilişkili hale gelmiştir. Yine ekonomik koşullar küçük yatırımcı için arsa temini ve finansman temini açısından karlı olan yap-sat sistemini özendirmiştir (Tekeli, 2011, s. 283-287).

1983'te Kat Mülkiyeti Kanunu'nda yapılan bir düzenlemeyle proje aşamasında ya da inşaat aşamasında satış yapma imkânına kavuşan ve yapım öncesinde finansman sağlayan küçük yatıımcı yap-satçı firmalar son 34 yılda sat-yapçı büyük inşaat firmalarına dönüşmüştür (Keleş, 2000, s.339-340). Büyük sat-yapçı firmaların çoğunluğu 2007 "Mortgate Yasası" ile birlikte finansal avantajlar nedeniyle Gayrımenkul Yatırım Ortaklığı (GYO) kurma yoluna gitmişlerdir. İnşaat yetkisi olmayan büyük GYO'lar da küçük taşeron inşaat şirketlerinin oluşmasında da rol oynamıştır. 1999 Marmara Depremi'nden 13 yıl sonra 2012 yılında yürürlüğe giren Kentsel Dönüşüm Kanunu ise yap-sat'ı parsel ölçeğindeki küçük yatırımcı/inşaat şirketleri için yeniden cazip hale getirmiştir.

1999 Marmara Depremi'nden tam 13 yıl sonra 2012 yılında yürürlüğe giren "Afet Riski Altındaki Alanların Dönüştürülmesi Hakkında Kanun”; büyük inşaat şirketleri için alan ya da ada ölçeğinde arsa kıtlığına çözüm olurken, küçük şirketler için de parsel ölçeğinde yeniden yapım fırsatı yaratmıştır. Özellikle rant farkı yüksek olan bölgelerde kentsel dönüşüm çok hızı bir ivme kazanmıştır. TÜíK verilerine göre; son 2002'den 2020'ye kadar 11 milyonu geçen sayıda konut yapı ruhsatı, 2012 sonrası 500.000'den fazla müteahhit yetki belgesi alınmıştır (URL-1). 
$\mathrm{Bu}$ büyük ivmeyle yeniden ve daha da yoğunlaşarak şekillenen kentsel dokunun; fiziksel, sosyal ve ekonomik sorunları da beraberinde getireceği açıktır. Bu çalışmanın amacı; Türkiye'de özellikle son 70 yılda uygulanan konut politikalarının, konutun ve kentsel dokunun oluşmasındaki doğrudan etkisini göstermek ve kentsel dönüşüm süreciyle birlikte ortaya çıkması muhtemel fiziksel ve sosyal sorunlara dikkat çekmektir.

Araştırma alanı olarak İstanbul'da "kentsel dönüşüm" sürecinin en yoğun şekilde yaşandığı ilçe olan Kadıköy seçilmiştir (URL-2). Kadıköy'ün konut politikalarına göre değişimi/dönüşümü; mevzuat, imar planları, hava fotoğrafları, konut binalarının tarihi resimleri, yenilenen konutların eski ve yeni mimari projeleri arasındaki farklar üzerinden anlaşılmaya çalışılmıştır.

Makalenin ikinci bölümünde konutun ve kentsel dokunun "konut politikalarında ve planlama kararlarına" göre yaşadığı evrim; kanunlar, planlama kararları, tarihi hava fotoğrafları ve konut fotoğrafları yardımıyla tüm Kadıköy geneli için değerlendirilmiştir. Değişimin incelenmesinde dönemler; 1923-1950 Arası, 1950-1980 Arası, 1980-2002 Arası, 2002 ve Sonrası olarak gruplanmıştır. 2002 ve sonrası dönem için genel değerlendirmelere ilaveten, Kadıköy Merkez E-5 (D100) Otoyolu Ara Bölgesi Uygulama İmar Planı Alanındaki "riskli yapı tescil haritaları" üzerinden kentsel dönüşüm/yenileme kapasitesi çarpıcı bir şekilde ortaya konmuştur.

Üçüncü bölümde ise Kadıköy Merkez-E5-D100 Otoyolu Ara Bölgesi'nde "parsel ölçeğinde" kentsel dönüşüm kapsamında yenilenen konut binalarındaki değişim "öncesonra" mimari ruhsat projeleri yardımıyla her mahalleden seçilen bir konut binası örneği üzerinden irdelenmiştir. Örnek bina, her mahalleden yenilenmiş/yenilenmekte olan konut binaları arasından kat sayısı bakımından çoğunlukta olanlar arasından seçilmiştir. Bu bağlamda Kadıköy Merkez-E5-D100 Otoyolu Ara Bölgesi'ndeki 11 mahalleden 1'er konut binası seçilmek üzere toplam 11 konut binasının kentsel dönüşüm sürecinde "önceki ve sonraki mimari ruhsat projeleri" yardımıyla; daire sayıları ve kat sayılarındaki artış, konut planlarındaki ve kesit özelliklerindeki mimari değişimler değerlendirilmiştir.

Fikirtepe ve çevresi ayrı bir imar planı çalışması ile dönüştüğü için, Kadıköy Merkez (Moda, Rasimpaşa), Acıbadem, Koşuyolu ve Hasanpaşa Mahalleleri ise imar planı koşulları nedeniyle kentsel dönüşüm yoğunluğu düşük olduğu için nedeniyle bina/parsel bazında yapılan dönüşümde önce-sonra araştırması dışında bırakılmıştır.

Sonuçlar bölümünde; İstanbul'da kentsel dönüşümle birlikte en yaygın halini alan yapsat konut sunum kültürünün ve artan yapı yoğunluğunun, kentsel donatı alanlarının yetersiz kalmasındaki etkisi vurgulanmıştır. Konut politikaları ve kentsel dönüşüm süreci'nin Bağdat Caddesi'ni çevreleyen dokuyu nasıl etkilediği açıklanmıştır. Mevcut konut politikalarının ve yap-sat konut sunum kültürünün bizi taşıyacağı bir sonraki durak ve karşılaşııması muhtemel sorunlar Kadıköy örneğinden yola çıkarak tartışılmıştır.

\section{Konut Politikalarının Kadıköy'deki Yansımaları}

Konut ihtiyacının karşılanması amacıyla devletçe belirlenen önceliklere göre alınan yasal ve eylemsel önlemlerin tümüne konut politikası denilmektedir (Keles, 2000). Ekonomik politikalar ve konut politikalarına bağlı olarak gelişen ve değişen konut sunum biçimleri ise, toplumda konut sağlanmasında alışılmış olandır. Yani bir tür "habitus"tur (Tekeli,1982, s 57-101). 
Bu bölümde Kadıköy ilçesi örneğinde konut politikalarına, konut sunum biçimlerine ve bunların konutun ve çevresinin oluşmasındaki etkisine örneklerle değinilecektir. Kadıköy kısaca tanıtılıktan sonra Türkiye Cumhuriyeti'nde 1923 yılından günümüze kadar uygulanan konut politikaları, bunların Kadıköy'e fiziksel etkileri dört dönemde incelenmiştir. Bunlar; 1923-1950 dönemi, 1950-1980 dönemi, 1980-2002 dönemi ve 2002 sonrası şeklindedir.

\subsection{Kadıköy'ün Konumu, Nüfusu ve Mahalleleri}

Kadıköy, İstanbul'un Anadolu Yakası'nda yer alan bir ilçesidir. Anadolu Yakası'nın güney batısında bulunan Kadıköy, batı ve güneyde Marmara Denizi, kuzeyde Üsküdar, kuzeydoğuda Ataşehir ve doğuda Maltepe ilçeleriyle çevrilidir (Şekil 1). Toplam yüzölçümü 25,2 km²'dir. 2019 sonu itibarıyla nüfusu ise 482.713'dür (ADNKS, 2020). Konumu ile Anadolu Yakasının merkez ilçe işlevindedir. Kadıköy, Avrupa ile Anadolu'yu birbirine bağlayan O-1 ve D-100 karayollarının teğet geçtiği, E-80 Karayolu'nun (TEM) bir kolunun içine saplandığı, Marmaray ve Avrasya Tüneli tarafından beslenen yoğun bir ulaşım ağı içindedir. Ayrıca kökleri Osmanlı Dönemi'ne uzanan Bağdat Caddesi (Bağdat Yolu) yakanın en prestijli ulaşım aksıdır (Şekil 1).

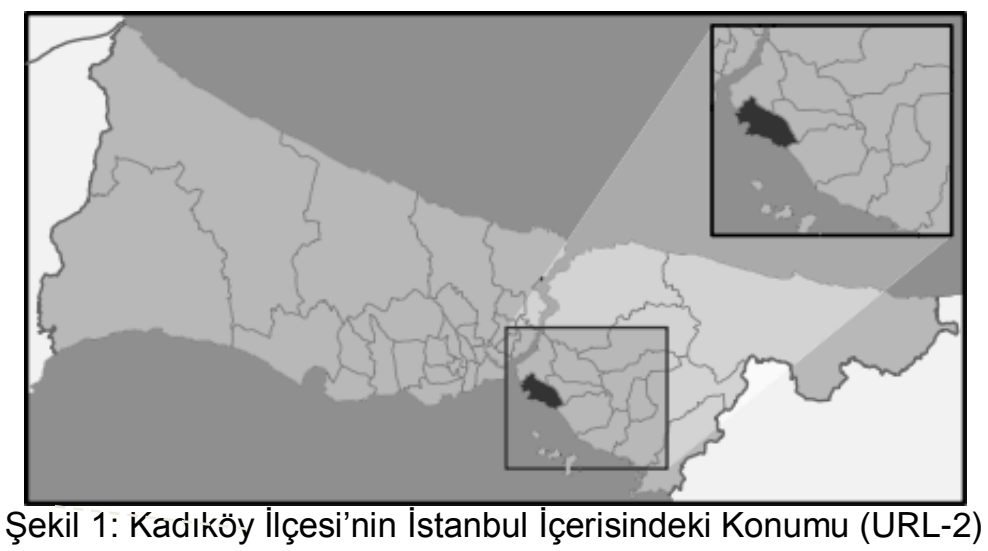

Deniz kenarında konumlanan Kadıköy'de, karayolu ve raylı sistemler dışında deniz yoluyla farklı ulaşım imkanları bulunmaktadır. Özel motor iskeleleri hariç, Kadıköy merkezde 4 adet ve Bostancı'da 2 adet olmak üzere toplam 6 adet yolcu iskelesi bulunmaktadır (Şekil 2). Kadıköy sadece geçiş alanı değil, aynı zamanda konut, iş, ticaret ve kültürel merkez alanı olarak (MiA) önem arz etmektedir (İBB İstanbul Çevre Düzeni Planı Raporu, 2009).

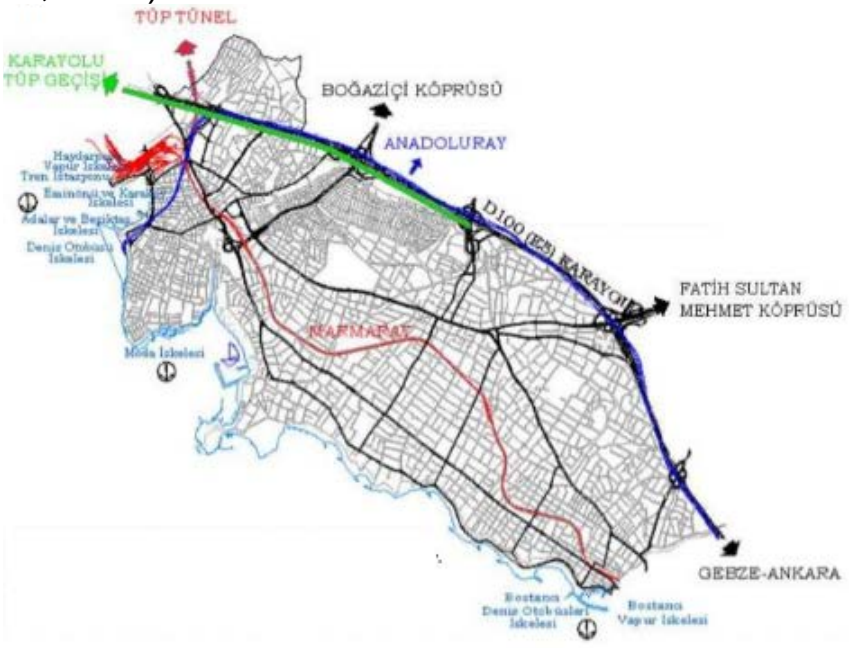

Şekil 2: Kadıköy IIlçesi Ana Ulaşım Bağlantıları, (URL-3) 
Kadıköy'ün Mahalleleri; 19 Mayıs, Acıbadem, Bostancı, Caddebostan, Caferağa, Fikirtepe, Göztepe, Hasanpaşa, Koşuyolu, Eğitim, Erenköy, Fenerbahçe, Feneryolu, Kozyatağı, Merdivenköy, Osmanağa, Rasimpaşa, Sahrayıcedid, Suadiye, Zühtüpaşa, Dumlupınar'dır (Şekil 3).

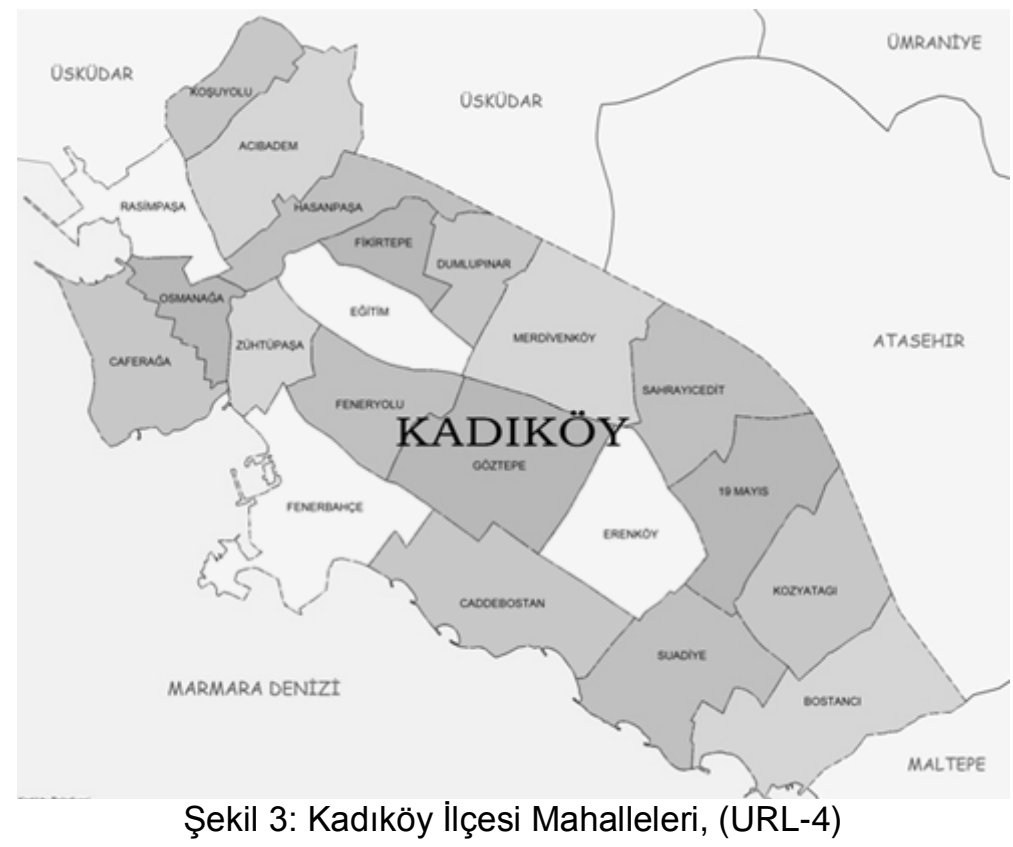

Kadıköy hem önemli bir konut yerleşim bölgesi hem de hizmet kenti olmasına rağmen tarihsel olarak baktığımızda İmar gelişiminde ölçek hiyerarşisine bağlı kalınmadığı, parçacıl planlama yaklaşımlarına görmekteyiz. Bu planlar; (1-2) Rasimpaşa Koruma Planı 1/1000 (Yeldeğirmeni Bölgesi), (3) Kadıköy Merkezi Bölgesi Nazım İmar Planı, (Caferağa, Osmanağa), (4) Acıbadem-Koşuyolu-Hasanpaşa Nazım İmar Planı (Acıbadem, Koşuyolu, Hasanpaşa), (5) Altunizade İmar Planı, (6) Fikirtepe ve Çevresi Nazım İmar Planı, (7) Kadıköy Merkez E-5(D-100) Otoyolu Ara Bölgesi Nazım İmar Planı şeklindedir (Şekil 4).

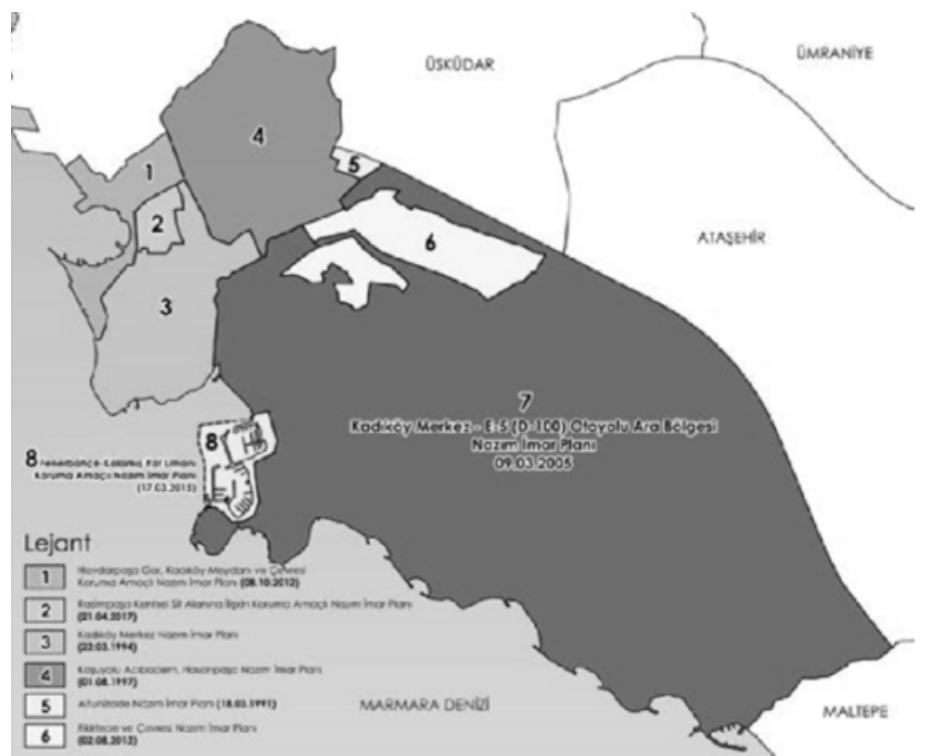

Şekil 4: Kadıköy İlçesi 1/5000 Ölçekli Nazım İmar Planları Planlama Alt Bölge Sınırları (URL-4) 
Araştırmada Kadıköy ilçesinde konut sunumu biçimlerinin keskin değişimler gösterdiği ve çok katlı bir dokunun baskın olduğu Fikirtepe ve Bağdat Caddesi Çevresi genel olarak haritalar ve planlar yardımıyla değerlendirilmiştir. Parsel ölçeğinde gerçekleşen dönüşüm ise (İkinci bölümde) özellikle "Kadıköy Merkez-E5-D100 Otoyolu Ara Bölgesi'ndeki 11 mahallede" detaylı olarak incelenmiştir.

Cumhuriyet öncesi döneme kısaca değinildikten sonra, Cumhuriyet Dönemi; 19231950 Arası, 1950-1980 Arası, 1980-2002 Arası ve 2002 Sonrası olmak üzere dört dönemde ele alınarak incelenmiştir. Konut politikalarının Kadıköy ilçesindeki etkileri; haritalar, imar planları ve fotoğraflar üzerinden incelenmeye çalışıımıştır.

\subsection{Cumhuriyet Öncesi Kısa Kadıköy Tarihçesi}

Fikirtepe'de yapılan kazılardan anlaşıldığı üzere Kadıköy'ün kuruluşu İstanbul'un kuruluşundan çok daha eski olan MÖ 3000 yılına dayanmaktadır. İlçenin eski adı olan Kalkedonya'nın (şimdiki Haydarpaşa Koyu ve Moda Burnu) körlerin yeri anlamına geldiği sanılmaktadır. Kökleri M.Ö. 3000 yıllarına dayanan Kalkedon adını alan şehrin yönetimi İstanbul'un fethinden sonra, II. Mehmed tarafından atanan İstanbul kadısı Hızır Bey'e verildiği için, yerleşmenin Kadıköyü adını aldığı sanılmaktadır. Rumların daha çok sahilde, Türklerin de daha gerideki bostanlık alanlarda yaşadığı belirtilmektedir (Ertuğrul, 2009, s. 293-312).

20. y.y.'ın başlarında Osmanlı'nın son dönemlerinde gerçekleştirilen Bağdat Demiryolu projesi kapsamında inşa edilen Haydarpaşa Garı ve Yeldeğirmeni yerleşimi günümüze kadar ulaşmıştır. Şekil 5'deki hava fotoğrafında Bağdat Demiryolu, Haydarpaşa Garı, Haydarpaşa Garı'nı inşa eden Almanlar ve İtalyanlar tarafından inşa edilen Yeldeğirmeni Mah. (Rasimpaşa Mah.) ve Moda yerleşim dokusu görülmektedir (Yavuz, 2008, s.299-311).

\subsection{3-1950 Dönemi Konut Politikaları ve Kadıköy’deki Yansıması}

Cumhuriyetin ilk yıllarında kentleşme hızı düşük olduğundan, en yaygın olan bireysel konut sunum biçimidir. Genellikle tek parsel üzerinde tek konut şeklinde ve konutu üreten kullanıcının gereksinimlerini ve toplumsal beğenileri göz önünde alarak (mülk konut şeklinde) gerçekleştirilmiştir.

Bu dönemde konut ve yerleşim sorununa ilişkin ilk girişim, 1923 yılında çıkarılan "Mübadele, İmar ve İskan Kanunu" kapsamında, Balkan Devletleri'nden gelecek olan Türk'lerin yerleştirilmesi amacıyla inşa edilen konutlarla ilgilidir. Yine 1926 yılında ilk olarak halkın inşaat teşebbüslerini desteklemek, gerekli kredileri sağlamak ve yetim haklarını korumak amacıyla Emlak ve Eytam Bankası kurulmuştur (Tosun, 2006, s.116).

1930 yılında ise, 1580 sayılı "Belediyeler Kanunu" ile tüm belediyelere imar planı yapma yetkisi ve konut sorununun çözümüne yardımcı olmak amacıyla belediyelere ucuz belediye konutları yaptırma görevi verilmiştir. Ancak belediyeler mali sorunlar nedeniyle bu görevi yerine getirememişlerdir. Tüm dünyada etkisi görülen 1929 krizi ile birlikte, ülkemizde de endüstrileşme planında konut sorununa yer verilmemiştir. İkinci Dünya Savaşı sırasında (1939), kiracıları da koruyan Milli Koruma Kanunu çıkartıımıştır (Toprak, 2001, s.187).

Yine 1930 yılında Türk nüfusun çoğaldığı Kadıköy, bağlı olduğu Üsküdar'dan ayrılarak ilçe olmuştur. Bu dönemde Osmanlı'nın son dönemlerinden kalma sivil mimari örnekleri olan konak ve köşklerin; Moda, Göztepe, Erenköy ve Bostancı Mahallelerinde çoğunlukta olduğu anlaşılmaktadır. Yapımı 17.yy.'la dayanan Bağdat Yolu'nun 
Fenerbahçe-Bostancı arasındaki kısmının 1934'ten sonra asfaltlanmasıyla bu seyrek yerleşim dokusunda Kadıköy'le Bostancı arasında yeni yapılar belirmeye başlamıştır (Bayhan, 2012, URL-5).

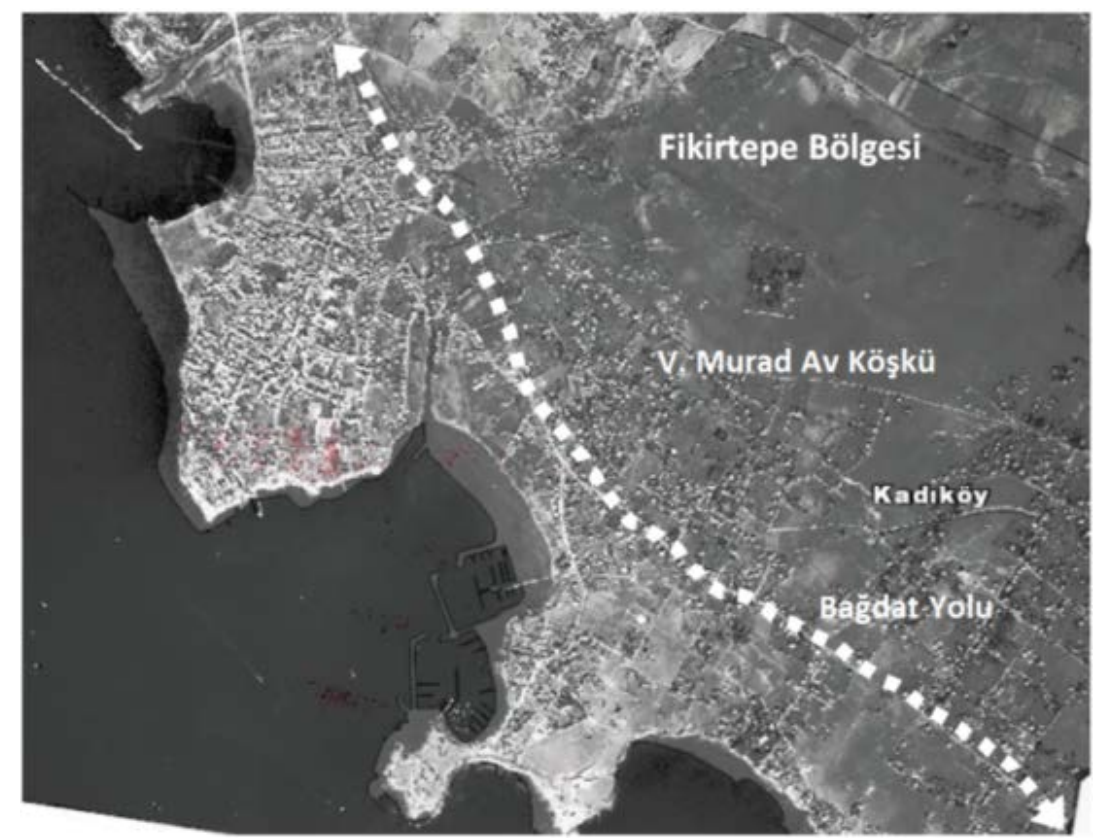

Şekil 5: 1946 Yılı Hava Fotoğrafı (URL-6)

Şekil 5'de 1946 yılına ait hava fotoğraflarında; Ayrılık Çeşmesi'nden başlayan Bağdat Yolu'nu ve Çevresi'ndeki bostanlıkları da içeren doku görülmektedir. Bugünkü Göztepe Minibus Caddesi hattının kuzeyinde yer alan Fikirtepe Bölgesi o dönemde tamamen kırlık yeşil alandır. Sadece Kadıköy merkezine ve yola yakın kısımlarda seyrek bir şekilde gecekondulaşmanın başladığı anlaşılmaktadır. 19.yy. başlarında inşa edilen V.Murad'ın av köşkü Fikirtepe'nin neredeyse tek yapısı olma özelliğini 1950'lere kadar sürdürmüştür (Ayık, 2014, s.80). 1940'larda Rasimpaşa (Yeldeğirmeni), Kadıköy Altıyol ve Moda'nın ahşap konutların yanısıra Tanzimat Sonrası kâgir apartman örnekleriyle yoğunlaşmıştır. Günümüze çok azı ulaşan köşkler dönemin yüksek kulelerinin gölgesinde kalmaktadır (Şekil 6).
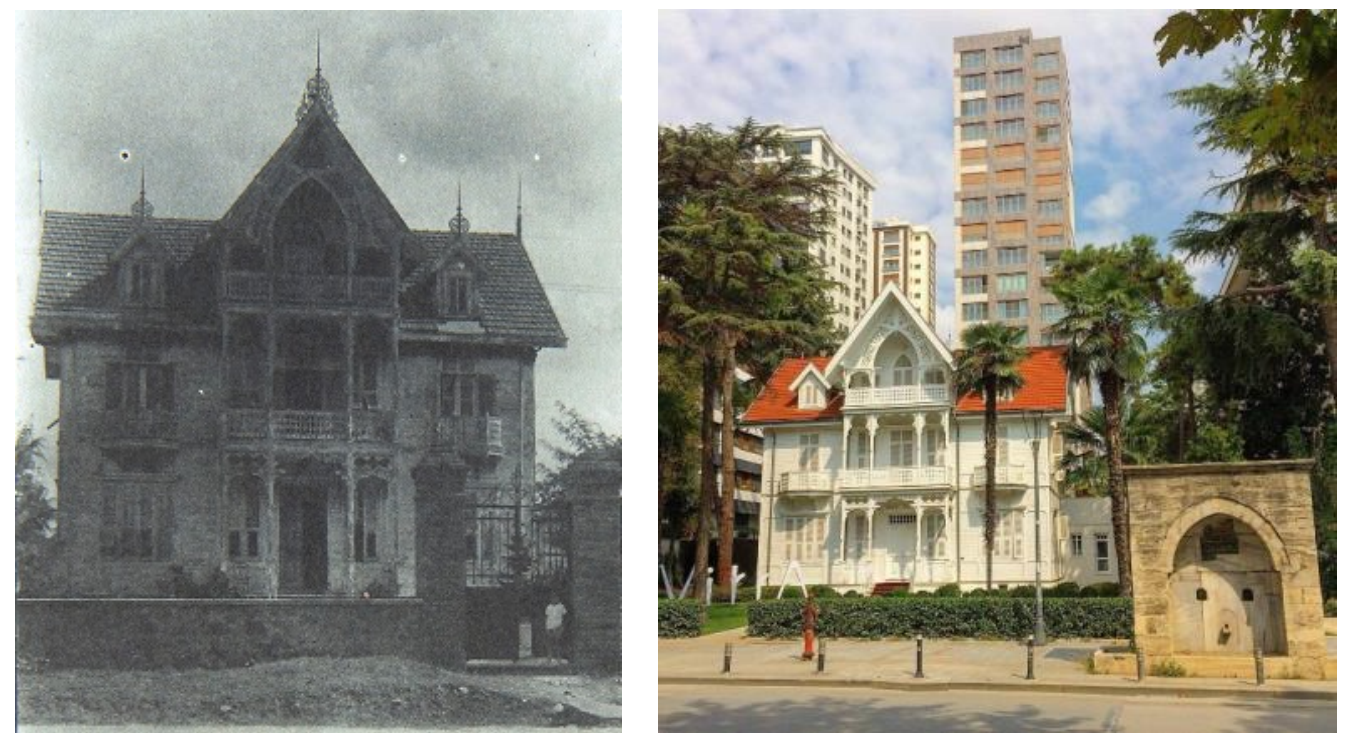

Şekil 6: Cavit Paşa Konağı, (URL-7) 
1930'lardan sonra Bağdat Yolu aksında ve demiryolu boyunca bahçe içinde iki katlı modern villalar inşa edilmeye başlamıştır. Osmanlı Dönemi'nden kalan köşkler ve daha sonra inşa edilen modern villalar "bireysel konut sunumu"nun en karakteristik örnekleridir (Özakbaş, 2015, s.283-309) (Şekil 6, Şekil 7).

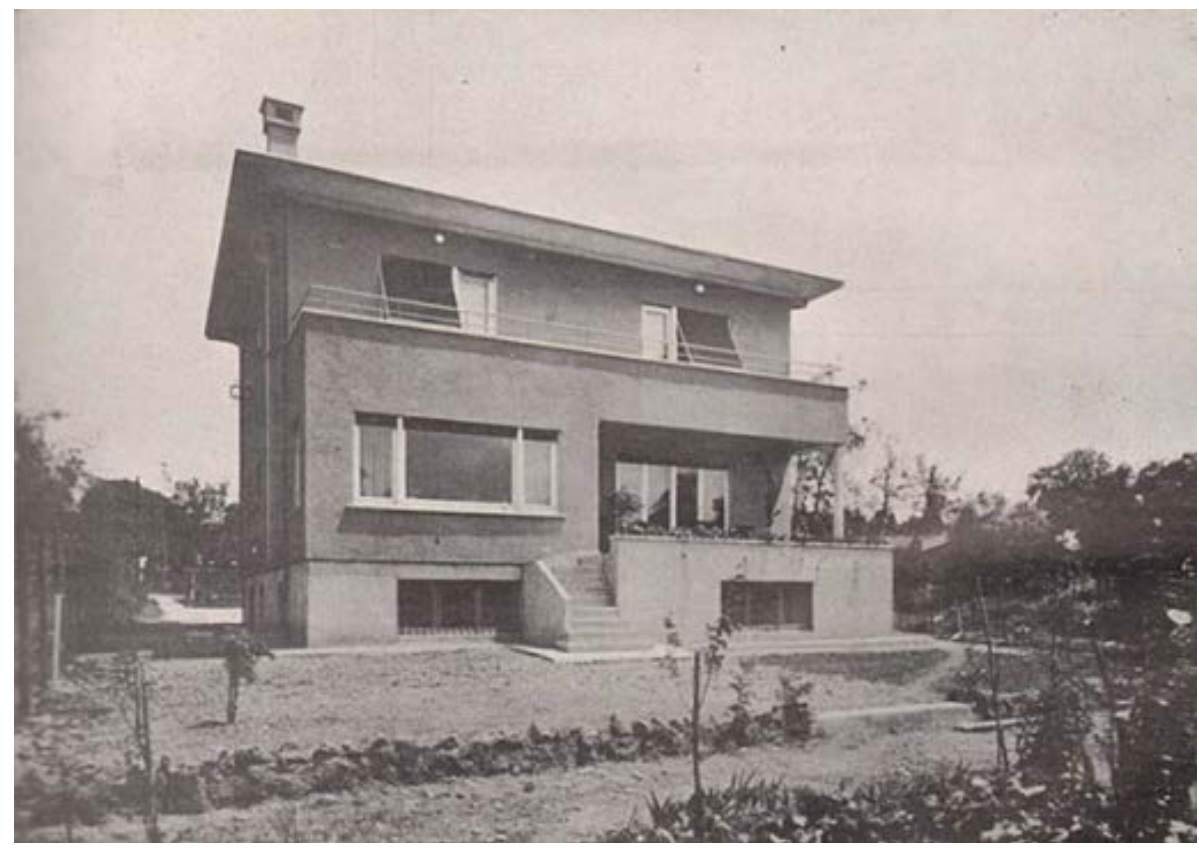

Şekil 7: Zeki Sayar, Kalamış'ta Villa Projesi (Arkitekt, 1937), (URL-8)

\subsection{0-1980 Arası Konut Politikalarının Kadıköy’deki Yansıması}

1950 sonrası endüstrileşme politikaları ve 27 Mayıs (1960) darbesiyle birlikte köyden kente göç eden nüfusun artışı, yapılı çevrede gecekondulaşmayı ve (özellikle 1970 sonrası) çok katlılaşmayı beraberinde getirmiştir.

Kente göç eden ve tutunmaya çalışan dar gelirli kesim gecekondu denilen kendi konut sunum biçimini yaratmıştır. "Illk dönem gecekondu üretimi kentte geçici olarak bir yer edinmeyi amaçlayan dar gelirli kesim tarafından, el yordamıyla, bilgi ve birikime dayanmadan yapılmıştır. Genellikle tek katı olan ve her türlü altyapı ve sosyal donatı hizmetlerinden yoksun olan, genelde şehir merkezlerinin hemen kıyısında öbeklenen yapılaşmadır (Keleş, 2000, s. 339-340)." 1960'larda sayısı ise 240.000'e ulaşan gecekondu yapımını engellemek ve yapılanları yıkmak amacıyla 1948 yılında 5228 sayılı Bina Yapımını Teşvik Kanunu ve 1953 yıında 6188 Sayılı Bina Yapımını Teşvik Kanunu ve İzinsiz Yapılar Hakkında Kanun çıkarılmış, fakat gecekondulaşma önlenememiştir (Sey,1998, s.285). 1958 yılında İmar ve İskan Bakanlığı kurulmuştur. 1961 Anayasasıyla birlikte dar gelirli ve yoksul ailelerin sağlık koşullarına uygun barınma ihtiyacını karşılama görevi devlete verilmiştir. Konut ihtiyacının karşılanması amacıyla gecekondu alanlarına alt yapı götürülmesi, gecekonduların iyileştirilmesi, kent imarı ve konut konusunda maliyetin karşılanması ilkesinin benimsenmesi, bütçe dışı kaynaklarla Toplu Konut Fonu oluşturulması ve konut kesiminde özelleştirme politikaları güdülmüştür. Ancak bu politikalar nitelikli kentsel doku yaratma bakımından Fikirtepe Bölgesi'nde başarılı olamamıştır. Kadıköy Fikirtepe Bölgesi bu dönemde yaşanan gecekondulaşmanın yaşandığı en çarpıcı örneklerden biri olmuştur. 1966'da henüz Boğaziçi Köprüsü (15 Temmuz Şehitler Köprüsü) inşa edilmediği halde 1950'lerden sonra sanayi aksı olarak gelişen E5/Ankara Asfaltı'nın (D 100 Karayolu) çevresinde gecekondu mahalleleri oluşmuş, Fikirtepe'nin kırlık alanı yok olmuştur (Şekil 8). 


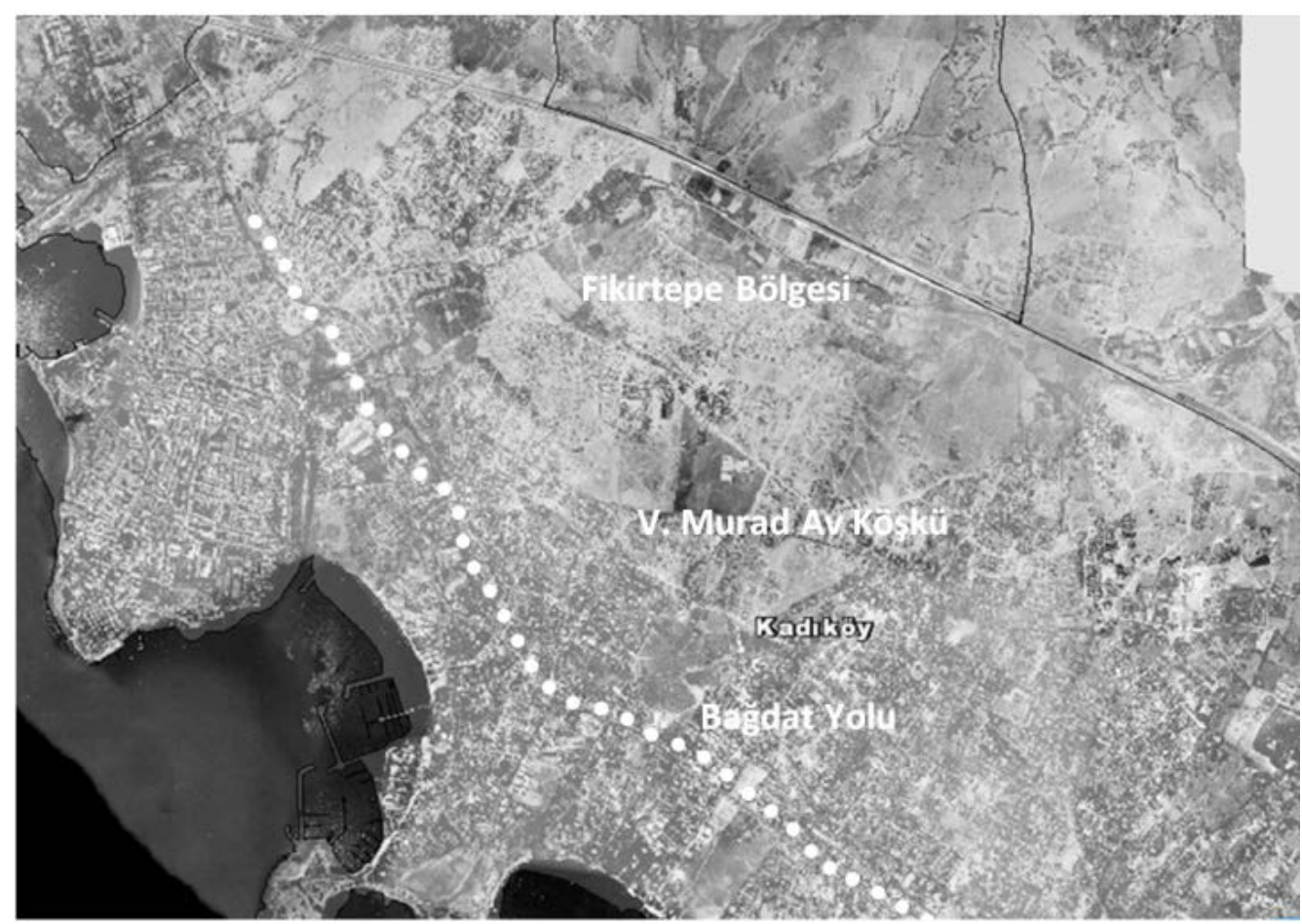

Şekil 8: 1966 Tarihli Hava Fotoğrafında Fikirtepe ve Bağdat Caddesi; (URL-6)

Yine bu dönemde, kentsel nüfustaki artış ve yığılmalar nedeniyle birden fazla hanenin yer aldığı çok katlı yapı blokları yani "sivil apartmanlaşma" başlamıştır (Balamir,1996, s.335-336). Ardından ortaya çıkan mülkiyetin paylaştırılması sorunu 1965 'te Kat Mülkiyeti Kanunu ile çözülmüştür. Böylece tek katlı yapının arsasına kat karşıı̆ı ortak olan müteahhitlerin belki de bir intiyaç sonucu ortaya çıkardığı yap-sat sunum biçiminin önü açılmıştır. Yap-sat basitçe bina yapıp satma işi olarak tanımlanabilir. Ancak en önemli özelliği genellikle yap-sat yüklenicisinin mülkiyet sahibi olmadığı halde yeni yapılan binanın bağımsız bölümlerinden bir kısmının mülkiyetini alarak (kat karşılığı sözleşmeyle) ya da arsanın tümünü satın alarak inşa faaliyetini üstelenmesidir.

1960'ların sonlarından itibaren Bağdat Yolu aksı ve çevresindeki; Göztepe, Erenköy, Caddebostan, Fenerbahçe, Suadiye ve Bostancı gibi semtler yap-sat yöntemiyle apartmanlaşmaya başlamışlardır. 1960 yıllarda yapılan E5(D-100) Karayolu ve 1973 yılında tamamlanan Boğaziçi Köprüsü (Yeni adıyla 15 Temmuz Şehitler Köprüsü) yapılaşma baskısını ve hızını arttırmıştır. Ancak bu yapılaşmanın şekli ve yeri sosyoekonomik duruma göre değişmiştir. Önceden çeperde yer alan tek katlı gecekondular şehir büyüdükçe merkezde kalarak rant değeri kazanmışlardır (Harvey, 2003, s.939-941). Aynı zamanda; çocukları yetişkin olan hane halkının artan konut intiyacının artması, 1966 'da çıkan 775 sayılı yasa ile gecekondunun ruhsatlanması, Kat Mülkiyeti Kanunu, tek katlı gecekonduların yap-sat inşaat yöntemiyle üretilen apartmanlara dönüşmesinde etken ve katalizör olmuştur (Şenyapılı,1998, s.301-316.).

Kadıköy Fikirtepe de plansız gelişerek tek katlı gecekondulardan, 3-4-5 katlı konut yapılardan oluşan dokuya bürünmüştür. Fikirtepe'nin 1946'da çekilmiş hava fotoğrafı (Şekil 5) ile 1966 ve sonrası çekilmiş hava fotoğraflarındaki (Şekil 8) fiziksel değişim dönemin sosyo-ekonomik durumunu ve uygulanan politikaların başarılı olamadığını göstermektedir. O dönemde (1946) Emlak Eytam Bankası'nın sunduğu 400.000 konuta (toplu konutun) ihtiyaç sahiplerinin erişemediğini göstermektedir (Görgülü, 2003, s.51). 
Kadıköy ilçesinde Bağdat Caddesi'nin ilk planlı gelişimi 1952-1954 döneminde olmuştur. Bu planlamayla Bağdat Caddesi ve çevresinde 3 katlı 9.50 kotunda yapılara izin verilmiştir. 1950'lere kadar Bağdat Yolu çevresinde devam eden müstakil, bahçeli ve seyrek yapılaşma Menderes dönemiyle birlikte değişmiş ve yerini 3 katlı (h:9,50) konutlara bırakmıştır. Bu dönemde Bağdat Caddesi ve Feneryolu'ndaki tramvaylar kaldırılmış, caddeye bakan bahçeler kamulaştırılmıştır (Güvenç, 1979, s.26-35).

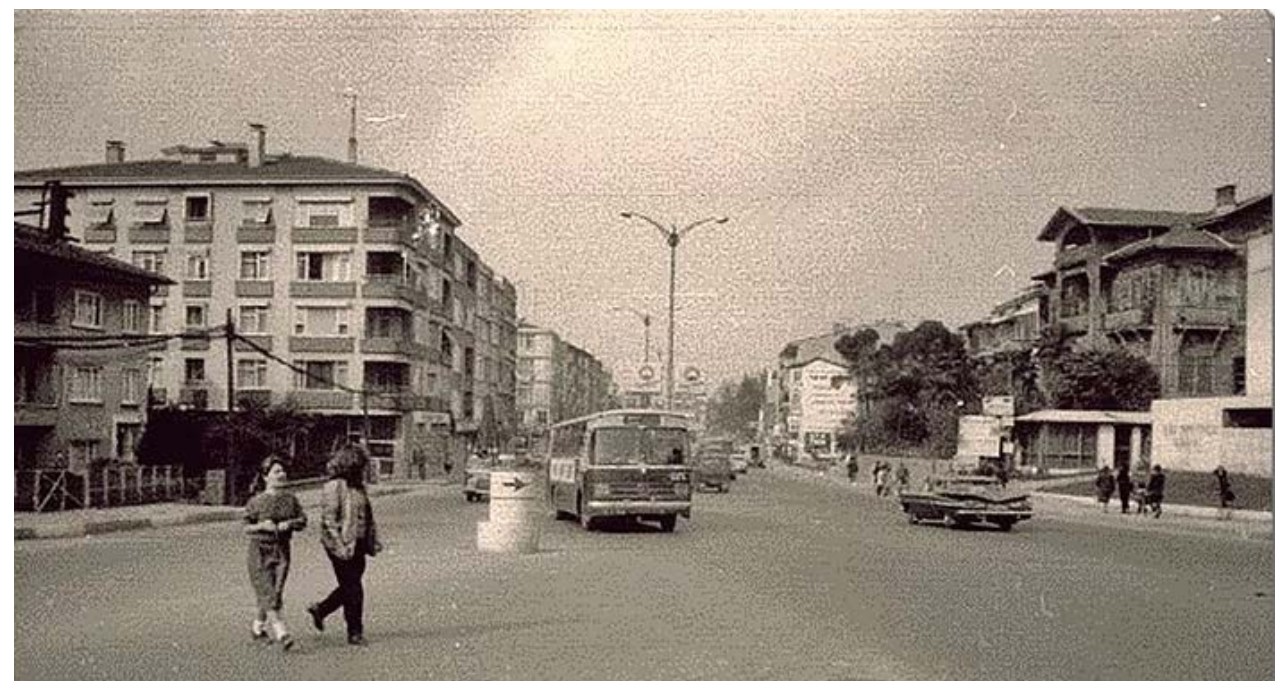

Şekil 9: Kadıköy -Kızıltoprak-Bağdat Caddesi Kavşağı 1970’ler (URL-9)

1965 'te Kat Mülkiyeti Kanunu'nun ve 1972 'de yapılan imar planı değişiklikleri yoğun apartmanlaşmanın önünü açmıştır. 1972 yılında hazırlanan 1/5.000 ölçekli BostancıErenköy Bölgeleme İmar Planı ile Kızıltoprak-Bostancı arasındaki yapı yoğunlukları arttırımış, kıyı parsellerinde 4 katı (h:12.50metre), Bağdat Caddesi üzerinde ise 5 katlı (h:15.50 metre) yükseklikte yapılaşmaya izin verilmiştir. Bağdat Caddesi ve demiryolunun iki tarafındaki köşk ve villalar dönemin yap-sat inşaat anlayışıyla apartmanlara dönüşmüştür. Şekil 9'da 1950'lerin 3 katlı kâgir konutları, 1970'lerin 5 katlı betonarme konutları ve 1900'lerin başlarına şahitlik eden ahşap köşkler bir arada görülmektedir (Şekil 9), (Güvenç, 1979, s.26-35).

\subsection{0-2002 Arası Konut Politikaları ve Kadıköy’deki Yansımaları}

1973'de açılan Boğaziçi Köprüsü (15 Temmuz Şehitler Köprüsü), Ankara Asfaltı da denilen D-100 karayolu bağlantısı ve 1984'ten sonra açılan Kadıköy-Pendik Sahilyolu 1980'li yıllarda 6 milyonu geçen İstanbul nüfusunun Kadıköy'e doğru yoğunlaşmasında etkili olmuştur. İstanbul'un iki yakası arasında ulaşım kolaylaşınca Kadıköy İlçesi'nde yeni yerleşime açılan seyrek düzenli apartmanlarda oturmak çekici hale gelmiştir.

1983 yılında Kat Mülkiyeti Kanunu'nda yapılan yeni düzenlemelerle "irtifak hakkı"nın tapulandırmayla satışı, yani yapım tamamlanmadan önce ruhsatı projeden satış mümkün olmuştur. Yap-sat konut sunumu "irtifak hakkı" satışılla zamanla "sat-yap" konut sunumuna dönüşmüştür. Neredeyse yatırımın tümünü önceden finanse edebilme imkânına kavuşan küçük yap-satçı şirketler zamanla büyük sermaye şirketlerine dönüşmüş ve daha çok orta üstü ve üst gelir grubuna hitap eden ve holdingleşen lüks konut projeleri sunmaya başlamışlardır (Aydın Gök, 2010, s.22-29).

Kadıköy'de 1973'te gerçekleşen imar tadilatıyla 1.8'e yükseltilen KAKS değeriyle; Erenköy, Göztepe ve Kozyatağı mevkilerinde konutlarda 10 kata varan yapılaşmanın yolu açılmıştır. 2000'li yıllara kadar D-100 karayoluna doğru yükselen bir kentsel doku 
oluşmuştur. Birden fazla parsel üzerinde yapılaşmaya ve kat irtifakı tapusuyla satışa imkân veren Kat Mülkiyeti Kanunu düzenlemesiyle "sat-yap" konut sunumu örnekleri Kadıköy'de de artmaya başlamıştır. Şekil 10'da dönemin projeden satış ilanı görülmektedir (Şekil 10).

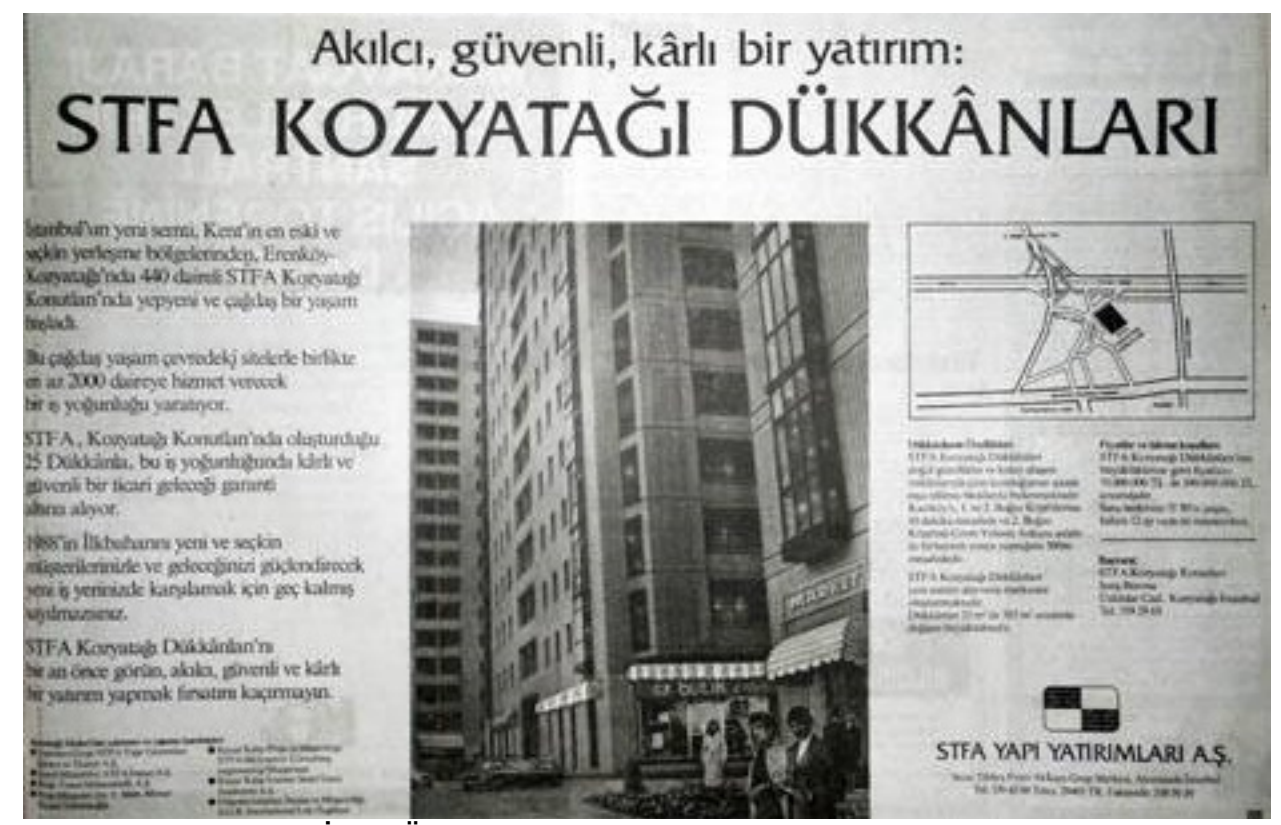

Şekil 10: 1988 Yılında İnşa Öncesi Satışa Sunulan Kozyatağı STFA Konutları (URL-10)

Yap-satçı konut sunumu ikinci bir gelişim alanını da gecekonduların apartmana dönüşmesinde bulmuştur. 1950'lerden sonra başlayan ve 1980'lerden sonra yeniden hızla artan gecekondular ve kaçak yapılar için 1984 yılında 2981 Sayılı İmar Affı Yasası'nın çıkması gecekonduları apartmana dönüştürmenin yolunu açmıştır. Yap-sat konut sunumunun daha küçük sermayeli yatırımcı tarafından yapılan örnekleri genellikle çeperdeki bu gecekondu alanlarında görülmüştür. Büyüyen kent içinde kalan gecekondu alanlarındaki yapıların kat sayıları da giderek artmıştır. Altyapı hizmetleri sonradan götürülmeye çalışılsa da plansız yapılaşan dokuda yoğunluk aşırı derecede yükselmiş, sosyal donatılarsa eksik kalmıştır. Fikirtepe'de de bu sürecin aynen yaşandığını anlaşılmaktadır. 


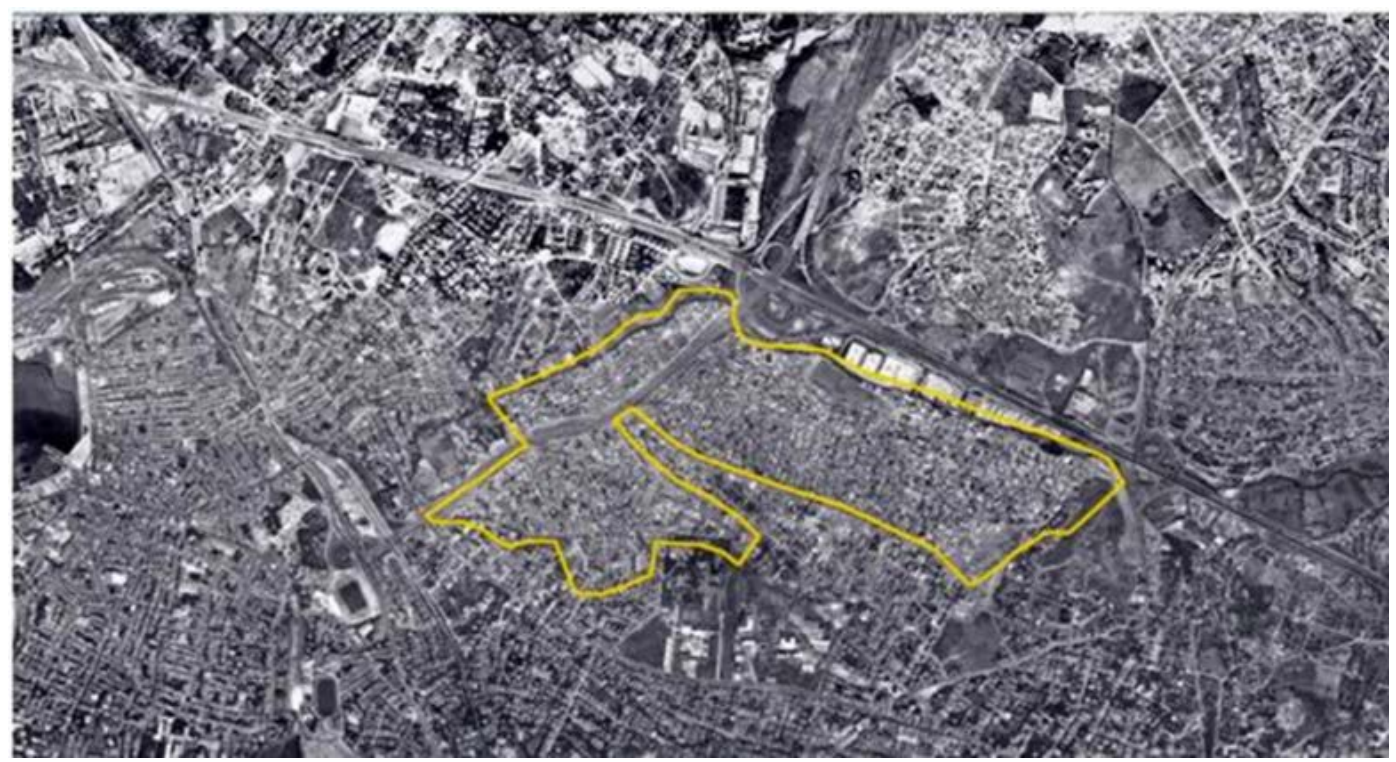

Şekil 11: 1982 Kadıköy Fikirtepe Mevkii Hava Fotoğrafı (URL-6)

D-100 ana ulaşım yolunun üzerinde kalan devletin hüküm ve tasarrufu altındaki Merdivenköy Fikirtepe Mevkii 1982 tarihli hava fotoğrafında görüldüğü gibi kaçak yapılaşmasını tamamlamış ve yukarıda bahsedilen 1984 sonrası imar affı kanunları ile özel mülkiyete geçiş sürecini tamamlamaya hazır hale gelmiştir. Şekil 11'de çizgi ile çerçevelenen alan, 2012 sonrası kentsel dönüşüm sürecine konu olan alandır (Şekil 11).

Bu iki tür yap-sat konut sunumu hızla devam ederken devlet nitelikli konut ihtiyacını toplu konutlar yoluyla karşılanmasına çalışmıştır. Yeni yasalar ve yeni finans kurumlarıyla desteklenen toplu konut sunumları 1980'ler sonrası yaygınlaşmıştır. Ülkedeki sosyal konut gereksinimini karşılamak ve bu gereksinmeyle ilgili finansmanı sağlamak üzere 1981 tarihinde 2487 sayılı "Toplu Konut Kanunu" çıkarılmıştır (Tapan,1998, s.376). Fonun yönetimi ve kanunun yürütülmesi için Toplu Konut İdaresi adıyla ayrıca yeni bir kurum da oluşturulmuştur (Sey, 1998, s.297). Toplu Konut Kanunu'nun yürürlüğe girmesi toplu konut projelerini hareketlendirmiş ve holdingleşen konut sunum şirketlerinin yanı sıra alışılagelmiş biçimde konut üretmek üzere birlikler biçiminde örgütlenen konut kooperatiflerini ve kent kooperatifçiliğini de oluşturmuş ve yaygınlaştırmıştır. Ancak 1990'lı yılların sonlarına doğru yeni yasal düzenlemelerle eski finansal desteği alamayan yapı kooperatifleri etkinliğini de kaybetmiştir. Bunda kooperatiflerin spekülatif kazanç elde etme aracına dönüşmesi etkili olmuştur (Özüerken,1996, s. 355-365).

1990'Iı yıllardan itibaren ilçenin D 100 Karayolu'nun kuzeyindeki alanlarında Emlak Bankası'nın kamu iştirakiyle ortaya çıkan "Ataşehir Toplu Konut Alanı" zamanla genişleyerek çevresindeki yapılaşmayı da kapsayan bir bölgenin adı olmuştur. Daha sonra 2009 yılında D 100 Karayolu'nun kuzeyindeki 7 mahalle Ataşehir adını alarak Kadıköy'den ayrılmıştır. Orta-üst gelir grubuna hitap eden Ataşehir bölgenin çekim gücünü arttırmıştır. Çevresinde küçük ve orta ölçekli yatırımcı tarafından yap-sat inşaat yöntemiyle üretilen yeni konutların sunulmasında öncü olmuştur (Dökmeci, 1995, s.26).

\subsection{2-Sonrası Konut Politikaları ve Kadıköy’deki Yansımaları}

2001 yılında yaşanan ekonomik kriz ve yolsuzluklar sonucu Türkiye Emlak Bankası tasfiye edilmiştir. Yeni hükümetin göreve gelişiyle birlikte 2003 yılında TOKi yeni yetkilerle donatılarak; yeni şirketler kurabilir, mevcut şirketlere ortak olabilir ve kâr amaçlı uygulamalar yapabilir/yaptırabilir duruma getirilmiştir. 
1999 'da yaşanan Marmara Depremi sonrasında yapıların daha sağlam inşa edilmesini sağlamak üzere; 2001 yılında 4708 Sayılı Yapı Denetim Yasası, 2007 yılında "26454 sayılı Deprem Bölgelerinde Yapılacak Binalar Hakkında Yönetmelik", 2008 Yılında 26778 Yapı Denetim Uygulama Yönetmeliği yürürlüğe girmiş Belediyelerin elinde olan ruhsat yetkisi Yapı Denetim Bürolarına paylaştırılmıştır. Hizmet ücretlerini dolaylı da olsa mal sahiplerinden veya yükleniciden alan yapı denetim firmalarının sorumluluklarını ne derecede yerine getirebildikleri hususu (üzerinde durulmadığı sürece) ancak bir sonraki depremde anlaşılacaktır.

2004 yılında 5612 sayılı yasa ile de TOKİ'ye imar planı yapma ve resen yürürlüğe koyma konusunda geniş yetkiler sağlanmıştır. Yine aynı yıl 5273 sayılı kanun ile Arsa Ofisi kaldırılarak yetki ve sorumlulukları TOKI'ye teslim edilmiştir. 2006 tarihli 5492 sayılı kanunla belediyelerin TOKİden asgari düzeyde harç alınması sağlanmıştır. Geniş yetkilerle ve avantajlarla donatılan TOKi ülkenin birçok ili ve ilçesinde sunduğu "sosyal konutlar"ın yanı sıra hasılat paylaşımı yoluyla ortaklıklar kurarak özellikle İstanbul, Ankara, İzmir gibi büyük şehirlerde "lüks konutlar" üretmeye başlamıştır.

Üretilen konut ve çevresinin kalitesini arttırmak ve konut edinimini kolaylaştırmak amacıyla konut finansman sisteminde değişiklik yapılması için, 2007 yılında 5582 sayılı yasa yürürlüğe konulmuştur. "Mortgage Yasası" da denilen bu yasa ile (1981 yılında kurulmuş olan) Sermaye Piyasası Kurulu'na bağlı olarak konut edinimi esnasında kullandırılan krediler ikincil piyasaya sunularak da fonlandırabileceklerdir. Ayrıca Gayrimenkul Yatıım Ortaklıkları (GYO) kurularak konut projesi geliştirilebilecek ve değerlerini ikincil piyasaya (borsaya) fon sağlamak üzere sunulabilecektir. Bu yasanın yap-satçı konut sunumu yapan bir kısım firmaları vergi muafiyetleri ve finansman olanakları nedeniyle GYO olmaya yönlendirdiği düşünülmektedir. Ancak yasaya göre GYO'ların proje geliştirip konut satabilmesine rağmen inşaat faaliyetinde bulunamamasının yeni yüklenici inşaat şirketlerinin sayısını arttırmıştır (GYO'lara İlişkin Esaslar Tebliği, 2013). GYO'lar ve büyük yap-satçı firmalar "lüks toplu konut" üretimi kapasitelerini arttırmışlar ve bunları yüksek duvarlarla çevreleyerek "kapalı site" içinde sunmuşlardır. Bir TOKi iştiraki olan Emlak Konut GYO A.Ş. de piyasadaki inşaat şirketleriyle ortaklıklar kurarak "kapalı site içinde lüks toplu konut" sunma yoluna gitmiştir. TOKI'nin bu dönem dar gelirli için sunulan en büyük kapasiteli tek toplu konut projesi ise 60.000 konutluk Kayabaşı Projesi olmuştur.

2011 yılında Devlet Planlama Teşkilatı kapatılmış Başbakanlığa Kalkınma Bakanlığı'nın Kurulmuştur. Aynı yıl Bayındırlık ve Bakanlığı da "Çevre ve Şehircilik Bakanlığı'na dönüştürülmüştür.

2012 yılında 28489 Büyükşehir Belediyeleri Yasası 1/5000 plan yapma yetkisine sahip 30 büyükşehir ortaya çıkmıştır. 2012 yılında yürürlüğe giren 6307 Mütekabiliyet Yasası ile yabancıya konut ve arsa satışının önü açıımıştır. Konut arzında oluşan fazlalığa talep yaratmak için yapılan bu düzenleme ekonominin çarkını döndürse de orta gelirli için bir türlü çözülemeyen konut sorununa yeni bir aktör daha eklemiştir.

Yine 2012 yılında "Kentsel Dönüşüm Kanunu" olarak da anılan "6306 Sayılı Afet Riski Altındaki Alanların Dönüştürülmesi Hakkında Kanun” yürürlüğe girmiştir. Böylece Türkiye Cumhuriyeti tarihinde görülmemiş büyüklükte (6,5 Milyon) konut stokunun yenilenmesini kapsayan bir "Kentsel Dönüşüm Süreci” başlamıştır (URL-11).

Boş arsa kıtlığı ve kuzeye doğru büyüme baskısı yaşanan İstanbul için, bir fırsata dönüşen "Kentsel Dönüşüm Kanunu", özellikle rant farkı yüksek (Fikirtepe, Bağdat Caddesi aksı vb.) alanlarda mevcut kentsel donatı üzerine yeniden daha yüksek 
yoğunluklu inşa/yapım süreci başlatmıştır. Kanunda belirtildiği üzere bu süreç "alan" (riskli alan) ve "parsel" (riskli yapı) ölçeğinde yürümüştür. Bakanlıkça Riskli Alan edilen bölgeler tümüyle yeni bir planlamaya konu edilirken, parsel ölçeğinde riskli yapı tespiti ise belediye, yapı denetim ve tescil kurumları vasıtasıyla yapılmıştır.

Bir yapının riskli tescili yapılması için mülkiyet sahiplerinden sadece birinin Kentsel Dönüşüm Bürolarına veya İlgili İdareye (belediyeye) başvurması yeterlidir. Eğer yapı depreme karşı riskli bulunursa 15 gün içinde itiraz hakkı olmakla birlikte mülkiyet sahipleri 60 gün içinde yapıyı yıktırmalıdır. Tescil kesinleşir ve yapı mülkiyet sahipleri tarafından yıkılmaz ise ilgili idare 60 gün içinde yıktırabilmektedir. Kentsel Dönüşüm Yasası, Kat Mülkiyeti Yasası'ndan farklı olarak paydaşların 2/3 çoğunluğu; yeni binanın projesine, yüklenicisine ve inşasına onay için yeterli görmektedir. Onay vermeyenlerin payları açık arttırmayla satın alınabilmektedir. Eğer gerekli anlaşma sağlanamaz ise Bakanlık, TOKI ya da İdare tarafından gayrimenkul üzerinde kamulaştırmaya gidilebilir (Kentsel Dönüşüm Kanunu, 2012).

Yeni, sağlam ve modern bir bina-konut sahibi olma isteğinin yanı sıra yeni finansman olanakları da dönüşüm furyasına katılımı hızlandırmıştır. Örneğin her daireye 125.000 TL'ye kadar TL düşük faizli kredi, 18 ay kira yardımı, ruhsat harçlarından muafiyet gibi avantajlar mal sahiplerini ve küçük yatırımcı müteahhitleri teşvik etmiştir. Ancak esas itici güç yeni binanın piyasa değerinin eskisine oranla spekülatif büyüklüğü ve kazancı arttıracak emsal (katlar alanı) artışlarıdır. Emsal alanı hesabının öneminin, Planlı Alanlar Tip İmar Yönetmeliği'nin 2013 yılında revize edilmesinde etkili olduğu düşünülmektedir. Bu yönetmelik en az \%20 emsal artışı imkanı yaratmıştır (Planlı Alanlar Tip İmar Yönetmeliği, 2013).

Sonuç olarak devlet politikalarıyla desteklenen konut ve inşaat sektöründe, alan ölçeğindeki büyük projelerde yatırımcılar; GYO’lar, TOKI ve İştirakleri iken, parsel ölçeğindeki projelerde; küçük inşaat şirketleri olmuştur. 2012 yılından 2020'ye kadar Türkiye genelinde 10 milyonu geçen sayıda konut için inşaat ruhsatı alınmıştır (URL-1). Çevre ve Şehircilik Bakanlığı'nın web sayfasında 2010 yılı verilerine göre Türkiye konut stokunu 19 Milyon, depreme dayanıksız konut sayısını 6-7 Milyon olarak açıklamıştı. (URL-12). İstanbul için ise yenilenmesi gereken konut sayısı 2,5 Milyon şeklinde ifade edilmekteydi. 2020 yılına gelindiğinde ise Çizelge 2.1.'de yer alan TÜíK verilerinden depreme dayanıklı konut intiyacı sayısal olarak karşılanmakta olduğunu görüyoruz (Çizelge 2.1). 
Çizelge 2.1. 2002'den 2019'a Türkiye ve İstanbul Genelinde Yapı ve İskân Ruhsatı Alan Konut Birimi/Daire Sayıları TÜIKK Verileri (URL-1)

\begin{tabular}{|c|c|c|c|c|c|}
\hline \multicolumn{3}{|c|}{$\begin{array}{c}\text { İskan Ruhsatı Alan Konut Birimi } \\
\text { Sayısı }\end{array}$} & \multicolumn{3}{|c|}{$\begin{array}{c}\text { Yapı Ruhsatı Alan Konut Birimi } \\
\text { Sayısı }\end{array}$} \\
\hline YII & Türkiye & İstanbul & YII & Türkiye & İstanbul \\
\hline 2002 & 161.491 & 10.237 & 2002 & 161.920 & 19.932 \\
\hline 2003 & 162.908 & 10.074 & 2003 & 202.854 & 30.835 \\
\hline 2004 & 164.994 & 10.632 & 2004 & 330.446 & 65.198 \\
\hline 2005 & 249.816 & 11.192 & 2005 & 546.618 & 126.246 \\
\hline 2006 & 295.389 & 16.084 & 2006 & 600.387 & 129.920 \\
\hline 2007 & 326.484 & 22.094 & 2007 & 584.955 & 153.951 \\
\hline 2008 & 357.286 & 26.275 & 2008 & 503.565 & 127.267 \\
\hline 2009 & 469.981 & 55.266 & 2009 & 518.475 & 105.502 \\
\hline 2010 & 429.755 & 55.233 & 2010 & 907.451 & 138.728 \\
\hline 2011 & 556.769 & 105.415 & 2011 & 650.127 & 147.862 \\
\hline 2012 & 556.331 & 98.546 & 2012 & 771.878 & 174.653 \\
\hline 2013 & 726.339 & 138.002 & 2013 & 839.630 & 167.305 \\
\hline 2014 & 777.596 & 148.306 & 2014 & 1.031 .754 & 219.476 \\
\hline 2015 & 732.125 & 148.497 & 2015 & 891.798 & 199.732 \\
\hline 2016 & 750.336 & 158.709 & 2016 & 986.119 & 213.526 \\
\hline 2017 & 817.000 & 160.157 & 2017 & 1.316 .023 & 253.649 \\
\hline 2018 & 890.590 & 157.406 & 2018 & 663.130 & 82.043 \\
\hline 2019 & 736.166 & 135.865 & 2019 & 321.787 & 50.640 \\
\hline Toplam & 7.534 .600 & 1.467 .990 & Toplam & 11.828.917 & 2.406 .465 \\
\hline
\end{tabular}

Ancak Çevre ve Şehircilik Bakanı tarafından aynı verilerin değişmeden ifade edildiğini görüyoruz (URL-13). Son 18 yılda 11-12 Milyon sağlam/yeni konut, intiyacı karşılayacak kapasitede sunulmuş olsa da bunların orta ve orta altı gelir grubunun edinemeyeceği fiyatta olduğu açıktır. Orta-üstü ve üst gelir grubunu hedefleyen konut arzındaki bu artış inşaat şirketleri ve piyasa üzerinde de baskı yaratmaktadır.

15 Temmuz 2016 'da gerçekleşen darbe girişimi sonrasında ekonomiyi canlandırmak ve artan konut arzını eritmek üzere 2017 yılında yeni düzenlemeler yapılmıştır. Bunlar; GYODER ve EMLAKGYO tarafından sunulan markalı konutlarda 20 yıl vadeli satış, KDV'nin \%18'DEN \%8'e indirilmesi, 1 milyon dolar değeri ve üzeri değerde konut satın alan yabancıya vatandaşlık verilmesi ve vergi muafiyeti (yabancıya konut satışı 2012 yılında yürürlüğe giren 6307 Mütekabiliyet Yasası ile başlamıştı) şeklindeydi. Daha sonra yabancıya vatandaşlık için satın alınan konutun sınır bedeli 250.000 Dolara indirilmiştir. Gayrimenkul ya da konut sertifikası satışı ile finansman sağlanması ve konut projelerinin borsada menkul değer haline gelmesi ve projeden konut satışında cayma hakkını kısıtlama şeklinde düzenlemeler ve uygulamalar da bu dönemde yürürlüğe girmiştir (URL-14).

Yukarıda anlatılan sürecin tüm yansımalarını Kadıköy'de görebiliriz. 2009 yılında Ataşehir Büyükşehir Meclisi'nin yeni düzenlemesiyle ayrıldı. Emlak GYO'ya dönüşen Emlak Pazarlama ve Proje Yönetimi A.Ş. ile TOKI Ataşehir'de müteahitlerle ortaklık kurarak ya da onları yüklenici yaparak Ataşehir'in Batı kanadını inşa ettiler. Bu alan da üst gelir grubunun edinebileceği fiyatlarla sunulmaktaydı (URL-15), (Şekil 12). 


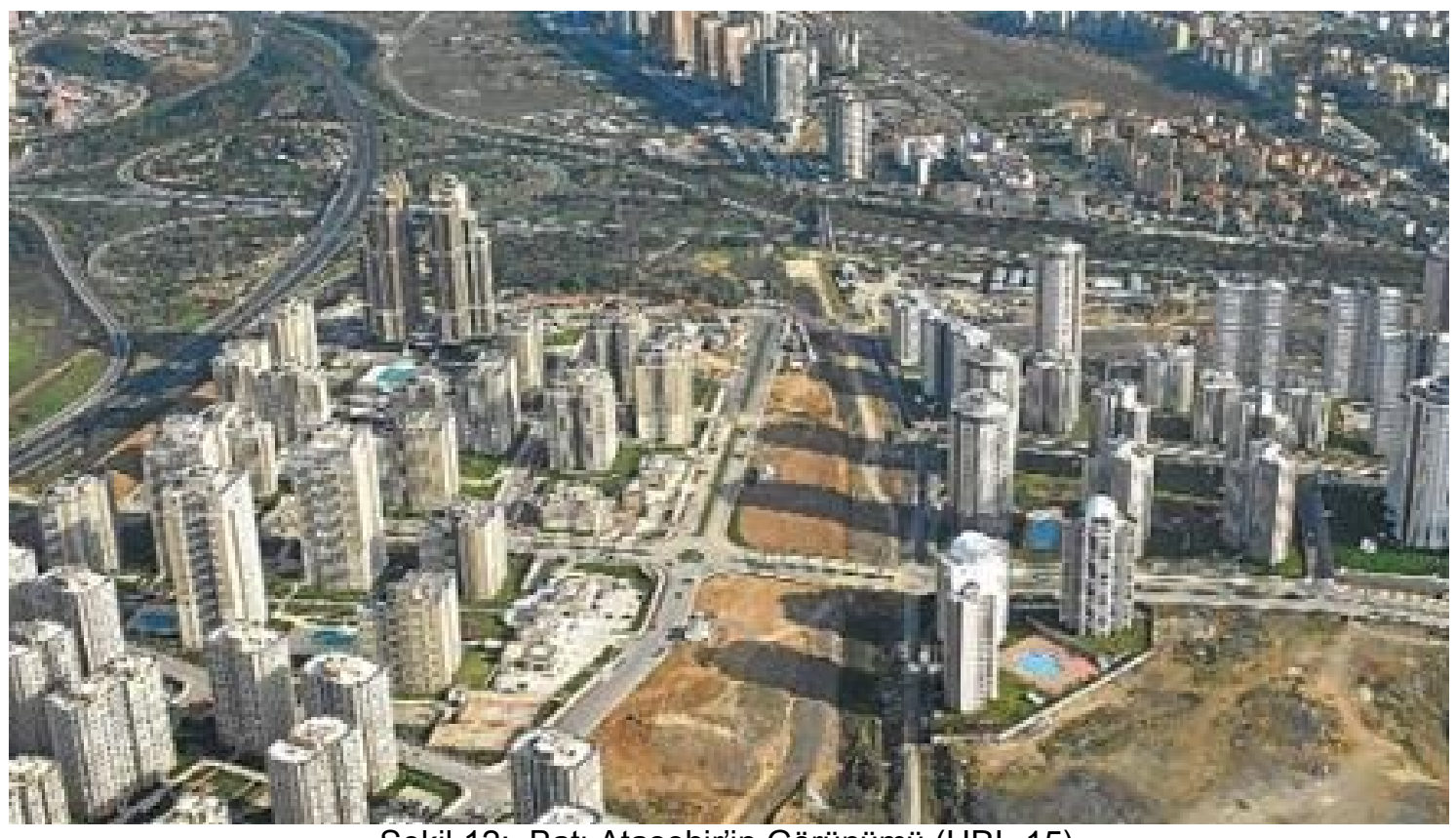

Şekil 12: Batı Ataşehir'in Görünümü (URL-15)

Kentsel Dönüşüm süreci bağlamında Çevre ve Şehircilik Bakanlığı tarafından Fikirtepe de riskli alan ilan edilmiştir. Fikirtepe'nin İmar Planı çalışmaları Kentsel Dönüşüm Kanunu'nun ilanından daha öncelerine 19842981 Sayılı Gecekondu Yasası sonrası geliştirilen 1991-1992-1995 tarihli Islah İmar Planları'na dayanmaktadır. Nihayetinde İstanbul Büyükşehir Belediyesi'nin kararıyla 22.02.2011 tastik tarihli 1/1000 Ölçekli Fikirtepe ve Çevresi Uygulama İmar Planı ile katlar alanı katsayısı (emsal) 1,10 ile 4,14'e kadar yükselmiştir. 2012 sonrası Kentsel Dönüşüm Kanunu'nun kabulünden sonra bu alan Çevre ve Şehircilik Bakanlığı tarafından riskli alan ilan edilmiş yeniden detaylandırılan plan 2014 yılında onaylanmıştır (Şekil 13), (URL-16).

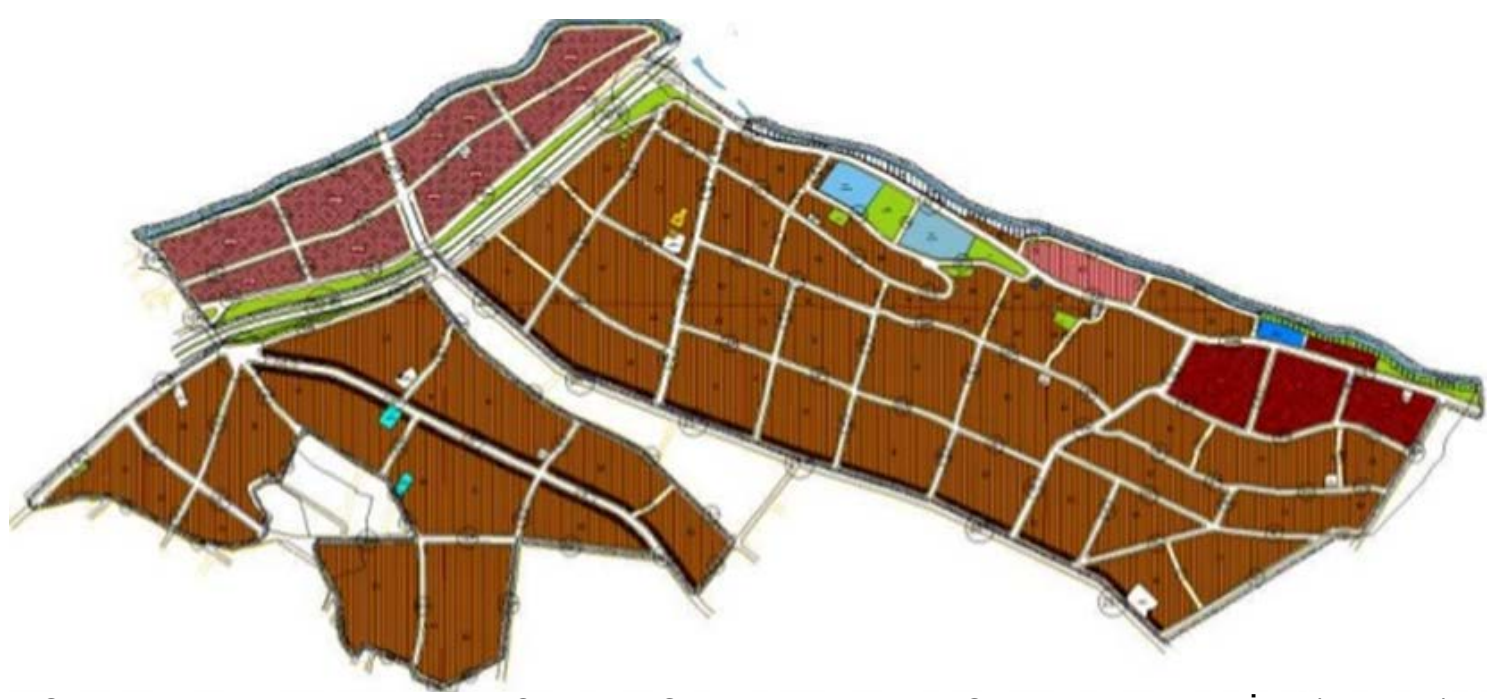

Şekil 13: 23.06.2014 tarihinde Çevre ve Şehircilik Bakanlığı Onaylı Fikirtepe U.İ.P. (URL-16)

Şekil 14'te 2013 yılında Fikirtepe'nin henüz yıkım başlamadan önceki hali görülmektedir. Mevcut yapılaşmanın yoğunluğu açıkça görülmektedir. 


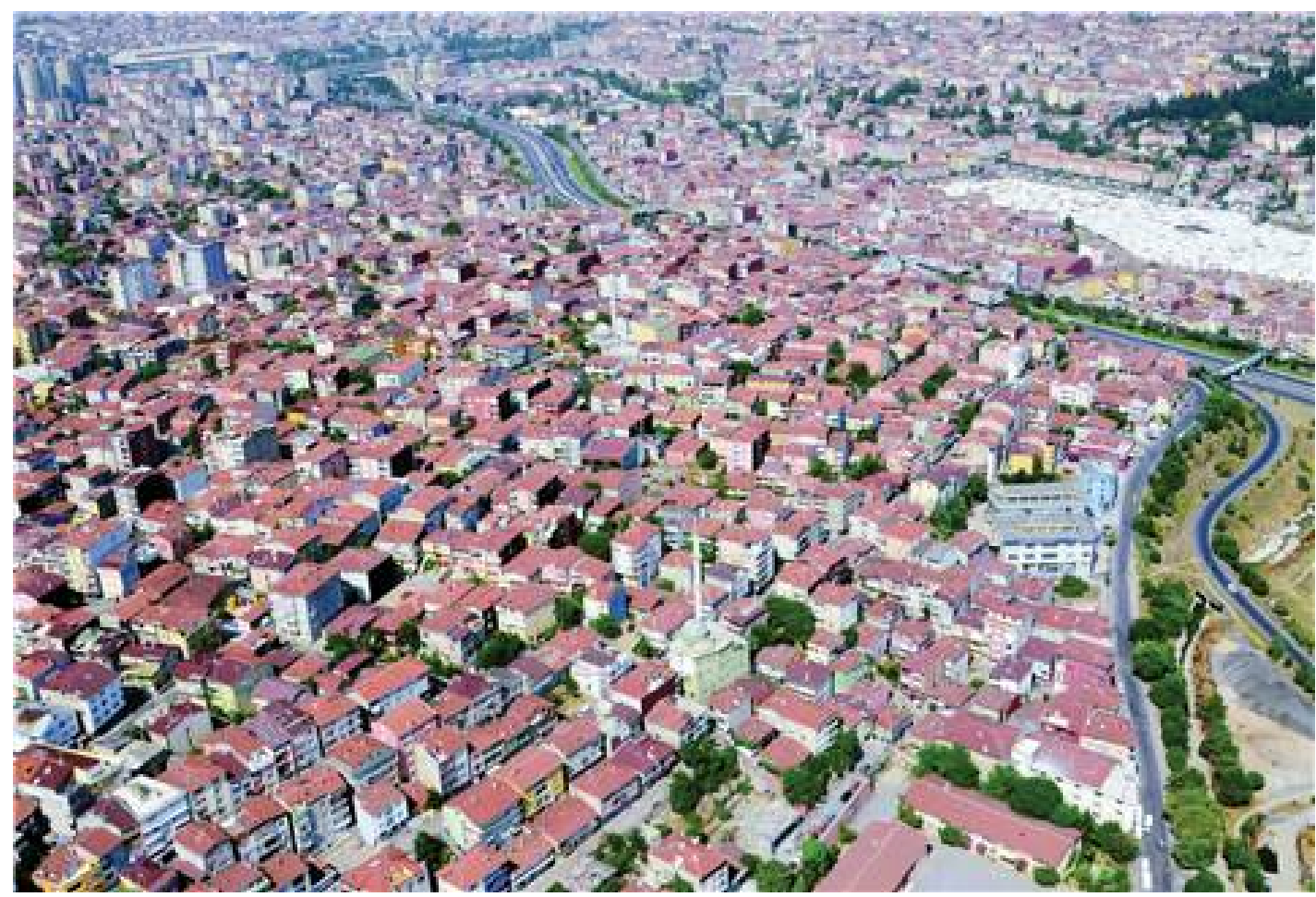

Şekil 14: Dönüşüm öncesi Fikirtepe 2013 (URL-17)

1970'lerde ve 80'lerde kaçak olarak yapılaşan ve çeperde kalan Fikirtepe, 2000'lerde merkezde kalan konumuyla yüksek rant vaat etmeye başlamıştır. Henüz 20 ya da 30 yıl geçmesine ve mevcut yüksek yoğunluğuna rağmen daha yüksek bir yoğunluk değeri olan 4,14 katlar alanı katsayısı ile yeniden yapılaşma sürecine girmiştir (Şekil 15). Şekil 15 'te yoğunluk artışının fiziksel etkisi üç boyutlu olarak görülmektedir. Ancak bu yoğunluk artışının sosyal ve çevresel etkilerine yönelik bir çalışma ile karşılaşılmamıştır.

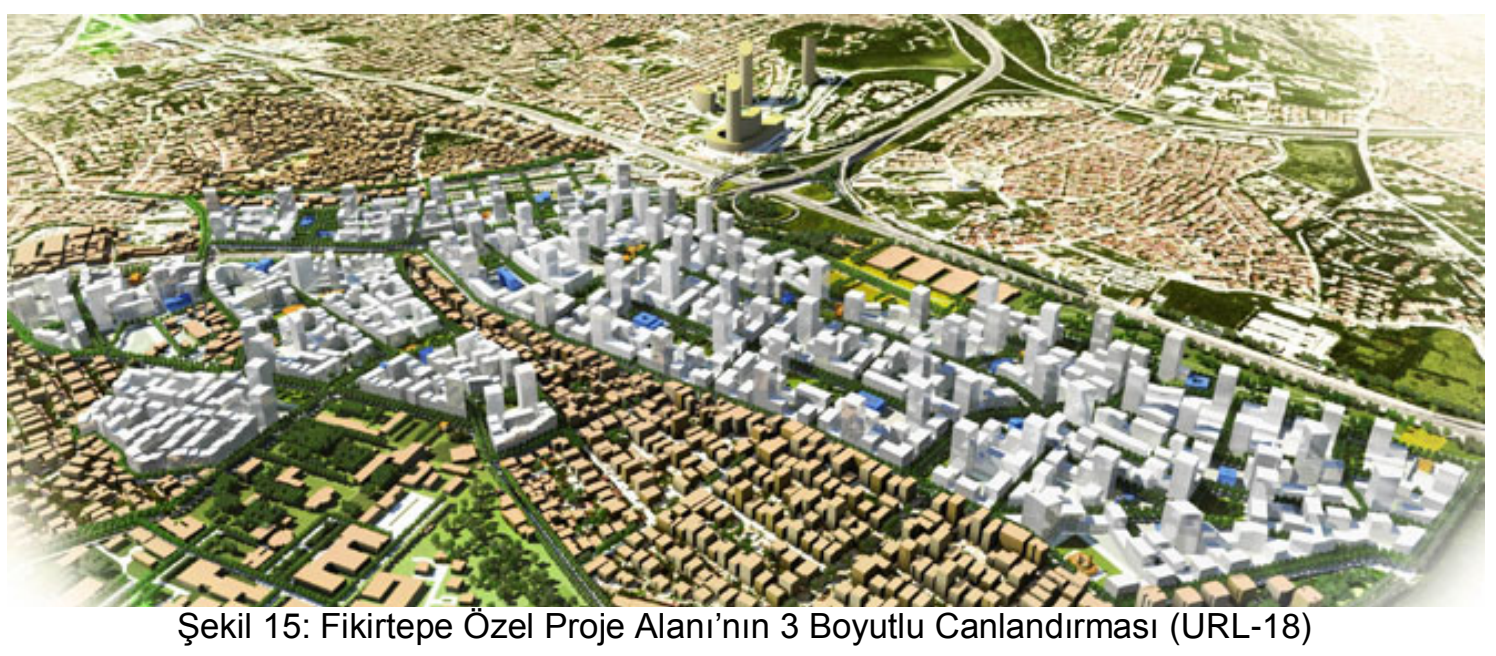

Kadıköy Belediye Başkanı Nuhoğlu 2017 yılının Şubat ayında verdiği röportajda “Kadıköy'de 30.000 konutumuz (binamız) var. Yani 200.000'nin üzerinde dairemiz var. 2012 'den bu yana 3.500'e yakın riskli bina tespit edildi. Bunların da 2.500'e yakını yıkıldı. Bunlar yenileniyor. Bütün bu yenlime süreciyle beraber şu anda nüfusumuz azalıyor; 452.000'e düştü. Bütün bunlar bittiği zaman 700.000'nin üstünde nüfusumuz olacak. Kadıköy 2.500 Hektar bir alan. Çok büyük bir alan değil. Bu 2.500 hektar 
alanda 700.000 nüfus büyük bir nüfus yoğunluğu olacak...." demiştir (URL-19). Fikirtepe Özel Proje Alanı'nın yanı sıra parsel ölçeğinde dönüşümün en çok görüldüğü bölge de D-100 karayolunun sahile kadar güneyini kapsayan bölümdür.

Şekil 16'da kentsel dönüşümün en yoğun olduğu bölge Kadıköy Merkez-E5-D100 Otoyolu Ara Bölgesi Nazım İmar Planı ile tanımlanan kısımdır (Şekil 16). İlk tasdik tarihi 2006 olan bu planla Emsal (KAKS) değeri 1,8'den 2,07'ye arttırılmış, yükseklik serbest bırakılmış ve TAKS:0,25 ile 0,35 seçeneklerinde tutulmuştur. 2017 yılında da kat yüksekliklerine sınırlama getirilmiştir (max.15 kat vb).

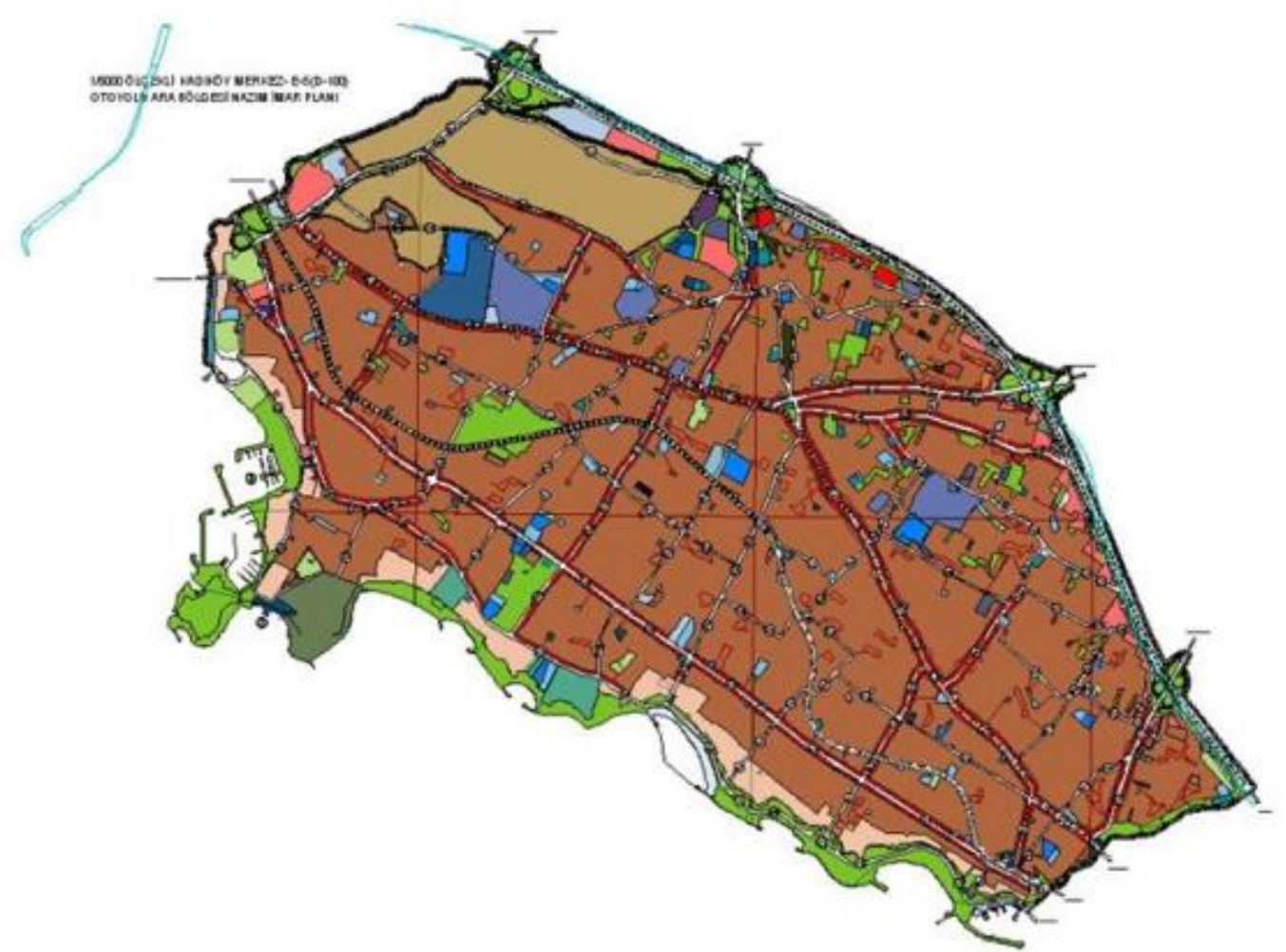

Şekil 16: Kadıköy Merkez-E5-D100 Otoyolu Ara Bölgesi Nazım İmar Planı (1/5000) (URL-16)

Ayıca Kadıköy Merkez-E5-D100 Otoyolu Ara Bölgesi Nazım İmar Planı notlarında taban oturumunda boş bırakılan (otopark vb) alanların $\mathrm{m} 2$ hakkını üst katlara transferine imkân veren bir düzenleme bulunmaktadır. Bu düzenlemenin fiziksel sonuçları 3. Bölümde gösterilmiştir. Kadıköy Merkez-E5-D100 Otoyolu Ara Bölgesi Nazım İmar Planı Bağdat Caddesi üzerindeki ve sahildeki binaların emsallerini arttırmamıştır (Şekil 16). 2006 onay tarihli plan koşulları 2012 tarihinden sonra Kentsel Dönüşüm Kanunu'nun yarattığı finansal olanaklar ve muafiyetler ile yap-satçı inşaat firmaları için çok avantajlı duruma gelmiştir. Planlı Alanlar Tip İmar Yönetmeliği'nden gelen emsal harici alan bonusu da (örn; merdivenler, balkonlar, kapıcı dairesi vb) da toplam inşaat alanlarını artıımıştır. Şubat 2017 de İBB Meclisi kararı ile Kadıköy İlçesi'ne getirilen 15 kat sınırı ile bölgenin yoğunluk artışı kontrol altına alınmaya çalışılmıştır. Ancak bu düzenlemede Fikirtepe kapsam dışı bırakılmıştır. Dönüşen yapılarda bodrum katların ön bahçe hariç parselin tümünü kullanarak otopark yapılması ağaçların yok edilmesine neden olmuştur. Kadıköy Belediyesi bunu önlemek için bodrum katın yan ve arka bahçelerden 100'er cm çekilerek inşa edilmesi kuralını getirmiştir. 


\section{Kadıköy Merkez E-5-D100 Otoyolu Bölgesinde (Bağdat Caddesi'ni Çevreleyen Alanda) Parsel Ölçeğinde Kentsel Dönüşüm Örnekleri Üzerinden Değerlendirmeler}

\subsection{Araştırma Alanı}

Konut Politikaları ve Kadıköy'de yapılaşma koşullarının değişimi hakkında genel bir değerlendirmeden sonra, bu bölümde "Kadıköy Merkez-E5-D100 Otoyolu Ara Bölgesi”nde (Şekil 16) parsel bazında gerçekleşen değişimler yansıtılmıştır. Öncelikle bu bölgedeki riskli yapıların tümünü gösteren harita Kadıköy Belediyesi Planlama Müdürlügü̈nden Ocak 2020 tarihi itibarı ile temin edilmiştir (Şekil 17).

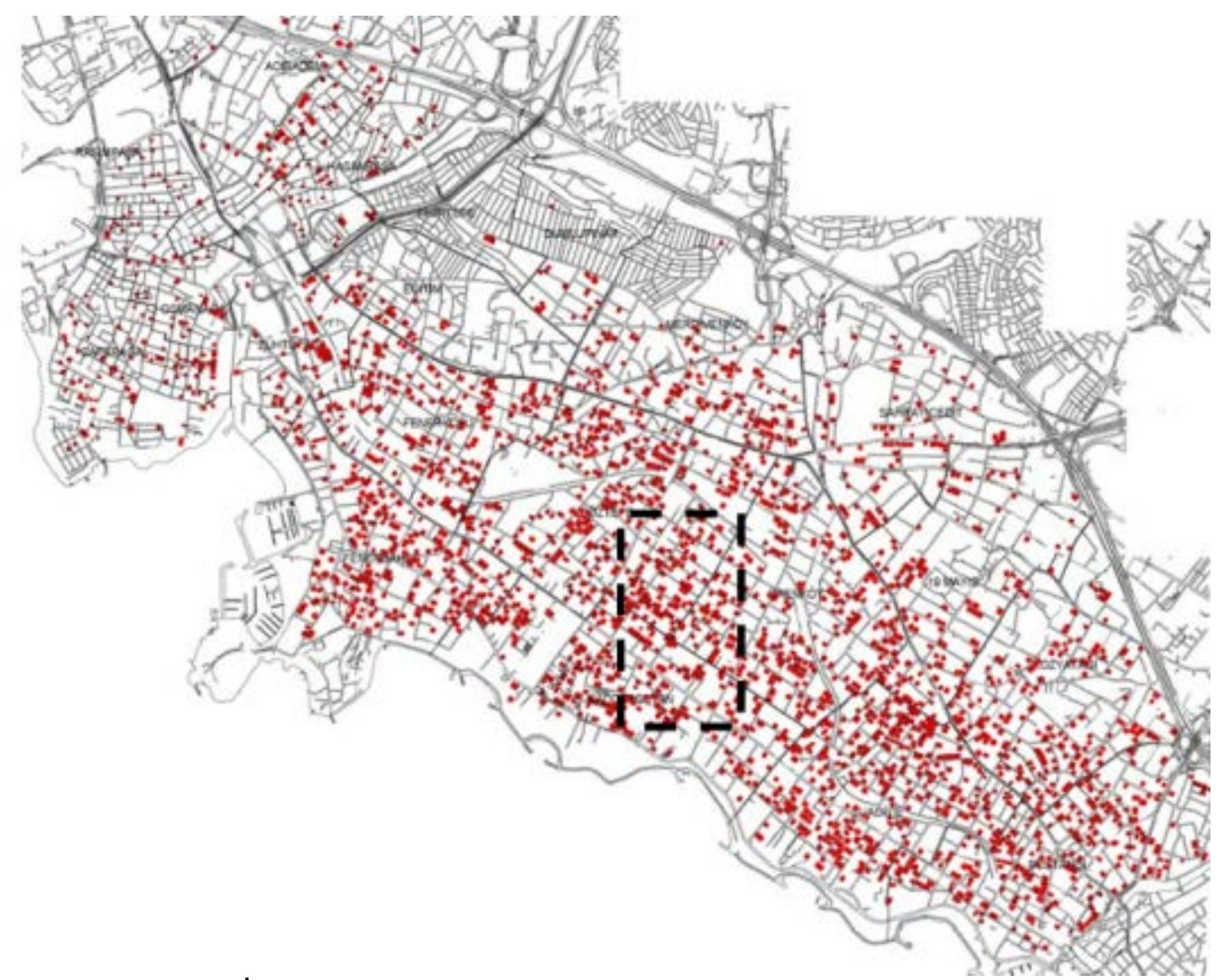

Şekil 17: Kadıköy İlçesi'ndeki (Fikirtepe Hariç) Riskli Yapı /Dokusu (Kadıköy Belediyesi, 2020) 


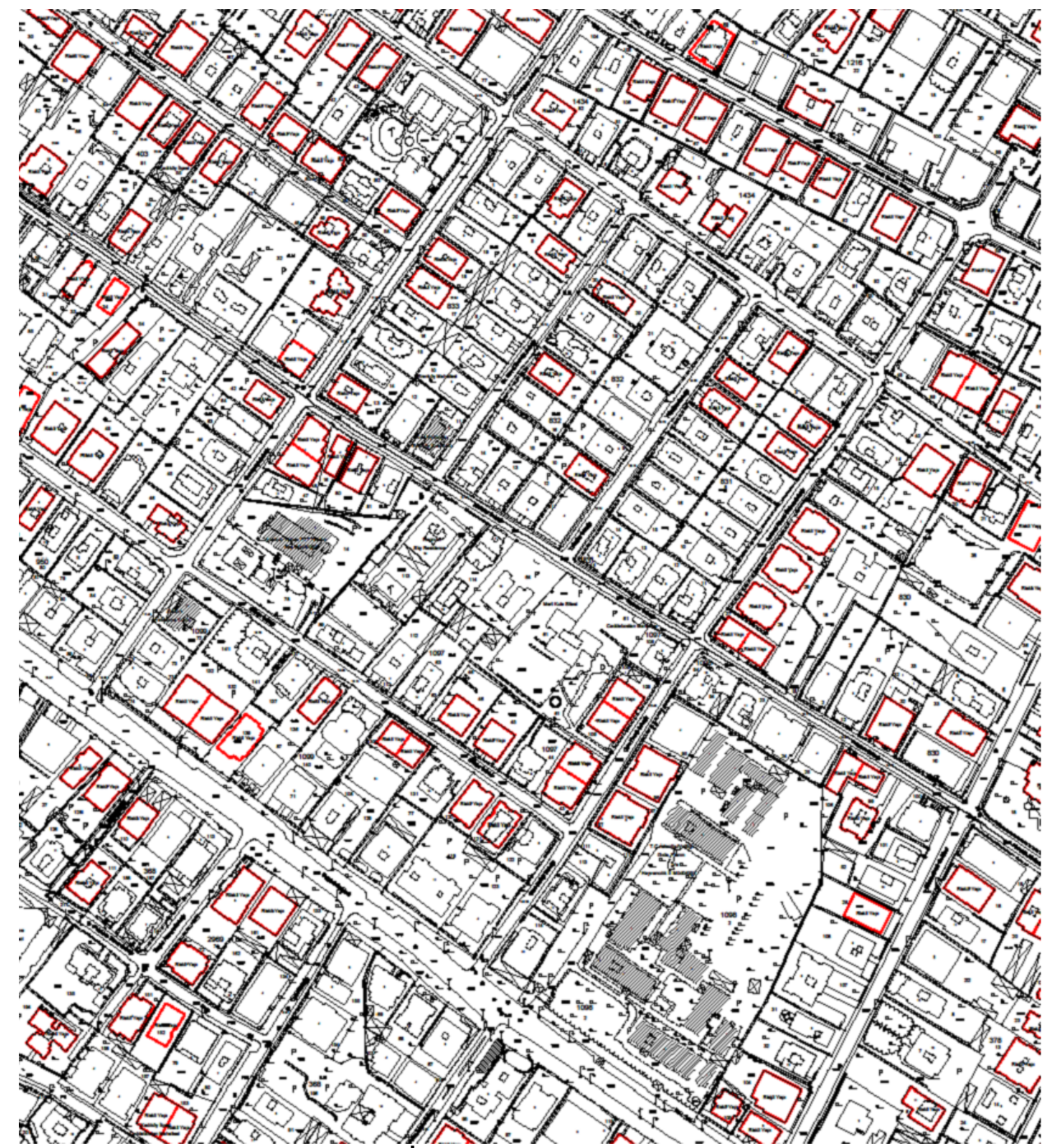

Şekil 18: Bağdat Caddesi Aksında Imar Adalarında Kırmızı Renkli Riskli Yapılar (Kadıköy Belediyesi, 2020)

2020 yılı Eylül ayı itibarıyla ile Şekil 17'deki haritada yer alan riskli yapı sayısı (Fikirtepe Kentsel Dönüşüm Alanı Hariç) 3770'dir (Kadıköy Belediyesi, 2020). Şekil 18'de yer alan ilgi haritaya göre her adanın ortalama \%30'unun veya \%40'ının riskli yapılardan oluştuğu görülmektedir (Şekil 17 ve Şekil 18) (Kadıköy Belediyesi, 2020).

\subsection{Araştırma Yöntemi}

"Kadıköy Merkez-E5-D100 Otoyolu Ara Bölgesi"nde yer alan 11 mahallede seçilen birer riskli yapı parselinde oluşan fiziksel değişim mevcut yapının ve yenilenen yapının mimari ruhsat projeleri yardımı ile anlaşılmaya çalışılmıştır. Kadıköy Belediyesi Planlama Müdürlüğü'nden temin edilen Riskli Bina Tespit Haritası (Şekil 17) üzerinden her mahalleden (11 mahallede) "en çok riskli yapı bulunan imar adasından birer konut binası/apartman" seçilmiştir. Örnek alınacak riskli yapının seçiminde; kat sayısı bakımından benzerleriyle birlikte çoğunlukta olması ve değişimi anlatmak bakımından çarpıcı olması belirleyici olmuştur. Dönüşüm öncesi ve sonrası dönemlere ait mimari ruhsat projelerinin pdf dökümanları Kadıköy' Belediyesi'nden temin edilmiştir. 19 Mayıs, Bostancı, Caddebostan, Göztepe, Erenköy, Fenerbahçe, Feneryolu, Kozyatağı, Merdivenköy, Sahrayıcedit, Suadiye olmak üzere 11 mahalleden 11 konut binasının kentsel dönüşüm süreci öncesi ve sonrası mimari ruhsat projeleri üzerinden; vaziyet 
planları, kat planları, kat sayıları ve yüksekliklerindeki değişim değerlendirilmiştir. Aşağıda mimari projelerinden resimler verilen 11 konut binasındaki 206 adet konut/daire çoğalarak 463 daireye dönüşmüştür. Bunun anlamı bir bina için ortalama \%100'lük bir yoğunluk artışı demektir.

\subsection{Vaziyet Planlarındaki ve Bodrum Katlarındaki Değişimin Yansımaları}

İlk tasdik tarihi 2006 olan Kadıköy Merkez-E5-D100 Otoyolu Ara Bölgesi Nazım İmar Planı Notlarına göre bölgedeki yapılaşma koşulları; TAKS(Taban Alanı Katsayısı):0,25 ile 0,35 arasında değişmektedir (Şekil 19).

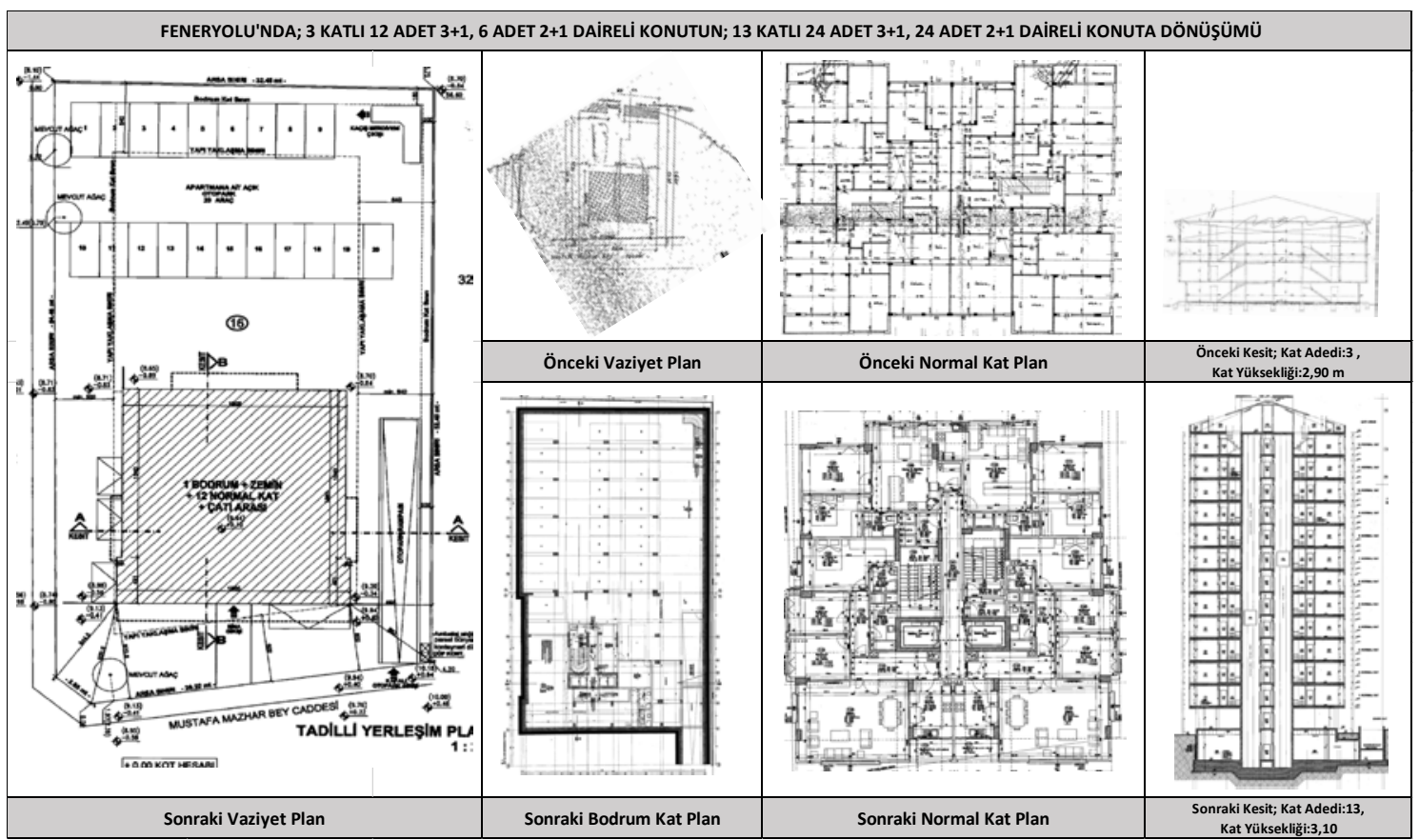

Şekil 19: Feneryolu'nda Yenilenen Konutun Dönüşümden Önceki ve Sonraki Mimari Ruhsat Projesinden Görünümler

Emsal/KAKS (Katlar Alanı Katsayısı):2,07 şeklindedir. Sahilde ve Bağdat Caddesi üzerindeki parsellerde emsal artışı planlanmamıştır. Ancak diğer kısımlarda emsal artışı ve yükseklik artışı söz konusu olmuş olacaktır. Konutlarda TAKS'ın 0,35 olması nedeniyle dönüşerek yenilenen binaların zemin oturumları büyümemiştir.

Ancak örneklerde de görüldüğü üzere kat sayıla 22 kata kadar artmıştır. Ayrıca bodrum katların neredeyse tümüyle garaj yapılmasının bir sonucu olarak oluşan toprak bahçeler yok olmuştur. Şekil 20'deki örneklerde bahçede hiç ağaç bulunmazken Şekil 19'daki örnekte birkaç ağacın korunduğu görülmektedir. Bodrum katların parsel sınırından en az 1,00 (metre) uzak olması sınırı da ağaçları korumak için yeterli olamamıştır (Şekil 19, Şekil 20). Bu sınır parsel boyutuna göre 1,50 m'den 3,00'ye kadar artmaktadır. $75 \mathrm{~m}$ parsel derinliğ inden sonra 3,00 m şartı getirilmiştir. 11 Örnekte de bodrum katlar garaj olarak düzenlenmiştir (Şekil 19, Şekil 20, Şekil 21, Şekil 22). 
Konut Politikalarının Fiziksel Yansımaları; Kadıköy Örneği

Physical Reflections of Housing Policies; A Samle of Kadıköy District

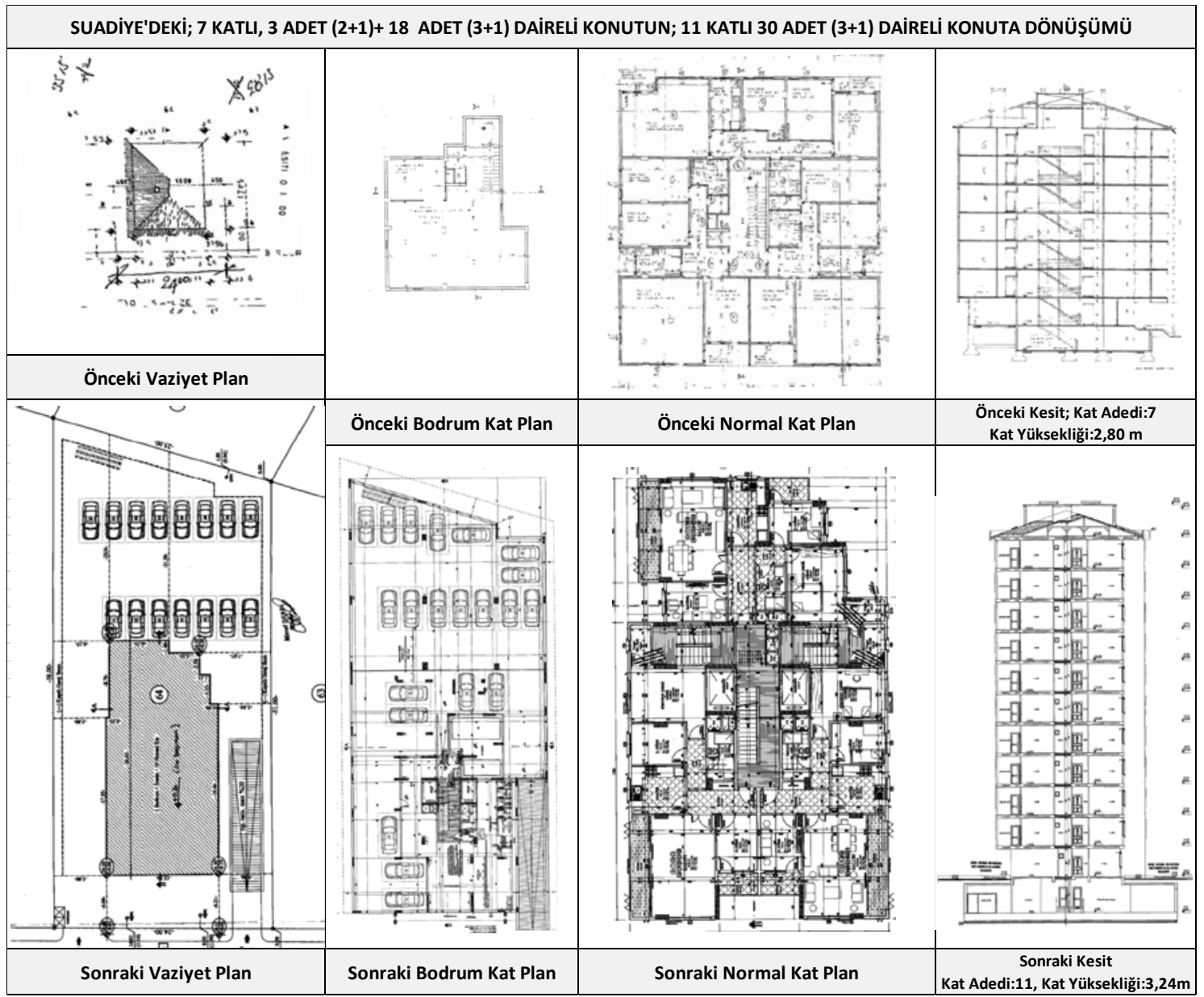

Şekil 20: Suadiye'de Yenilenen Konutun Dönüşümden Önceki ve Sonraki Mimari Ruhsat Projesinden Görünümler

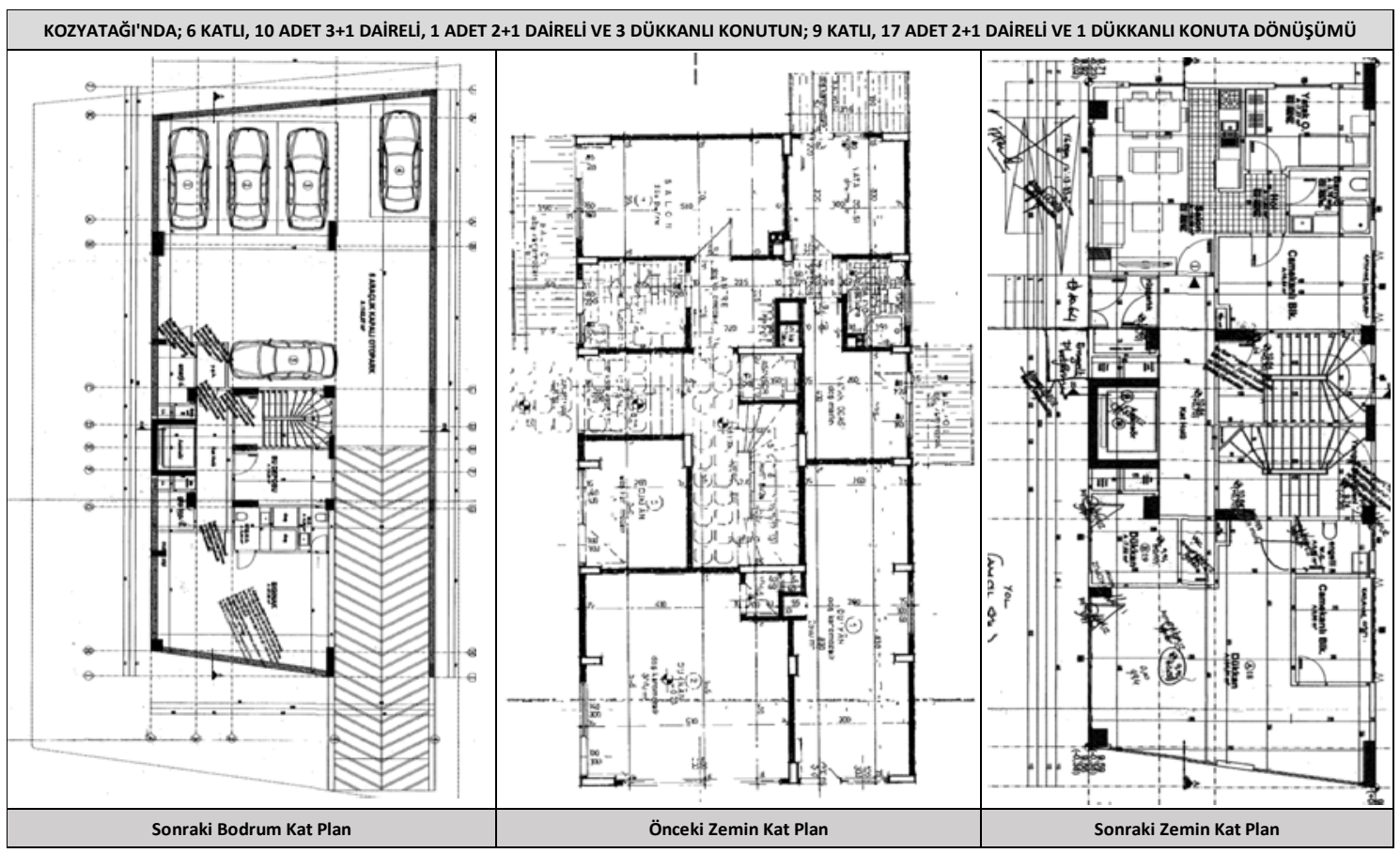

Şekil 21: Kozyatağı'nda Yenilenen Konutun Dönüşümden Önceki ve Sonraki Mimari Ruhsat Projesinden Görünümler 


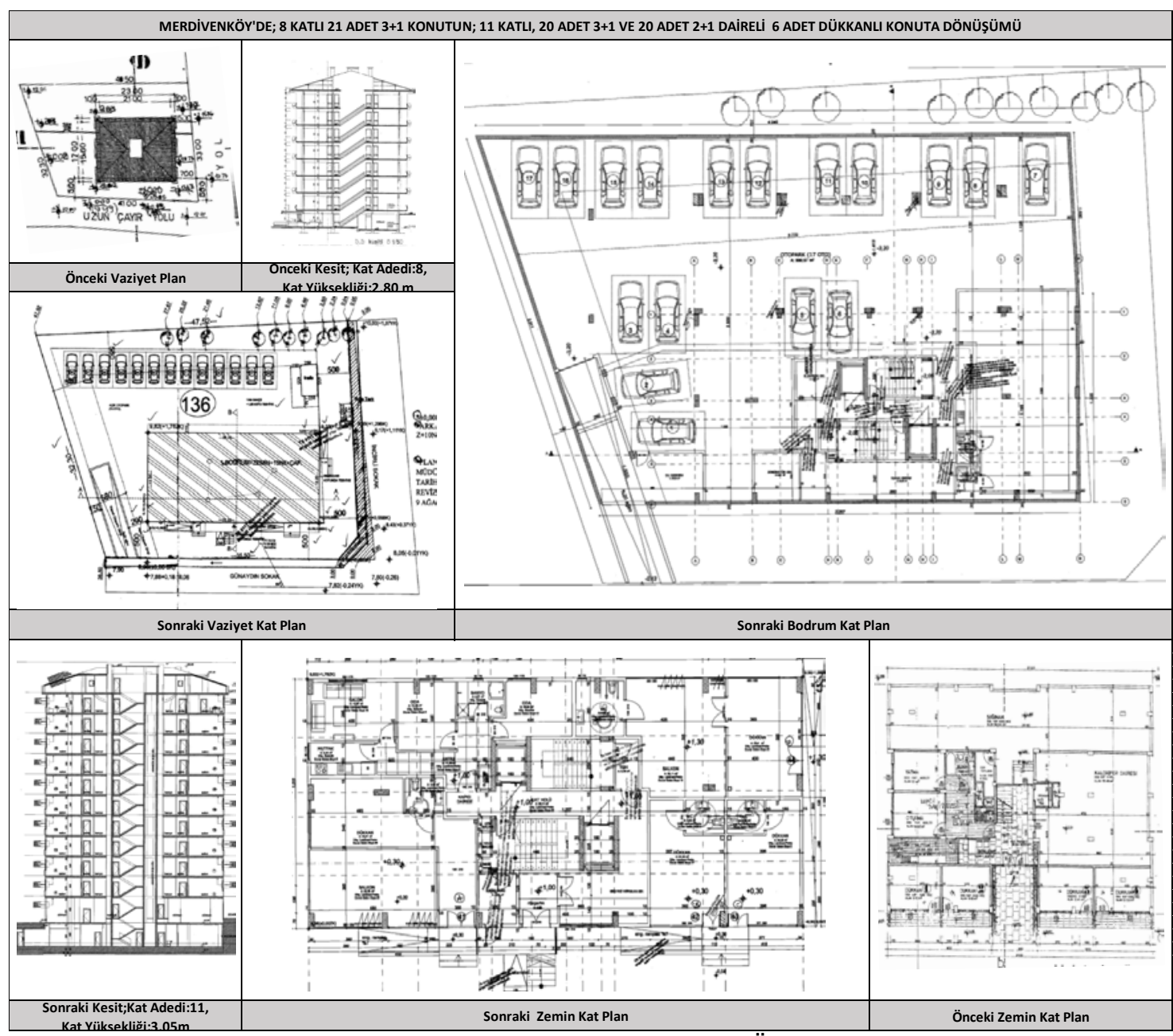

Şekil 22: Merdivenköy'de Yenilenen Konutun Dönüşümden Önceki ve Sonraki Mimari Ruhsat Projesinden Görünümler

\subsection{Zemin Kat Planındaki Değişimin Yansımaları}

Konut ruhsat projelerinin büyük çoğunluğunda (11 binanın 7'sinde) zemin kat planları Şekil 23'te olduğu gibi (kolonlar arasında) açık otopark olarak gösterilmiştir. Bunun sebebi ise plan notlarındaki, "zemin kat otopark olarak düzenlenirse katlar alanı hakkını yukarı katlara aktarabilme" imkanı tanıyan düzenlemedir. İnşaat sonrası çoğu yapının zemin katının projeden farklı olarak kapatıldığını görüyoruz. Şekil 23'teki yapının ruhsat projesinde zemin kat açık otopark olarak gösterilirken yerinde Şekil 24 'teki gibi zemin katın kapatılarak iskan edildiğini görmekteyiz. 
Konut Politikalarının Fiziksel Yansımaları; Kadıköy Örneği

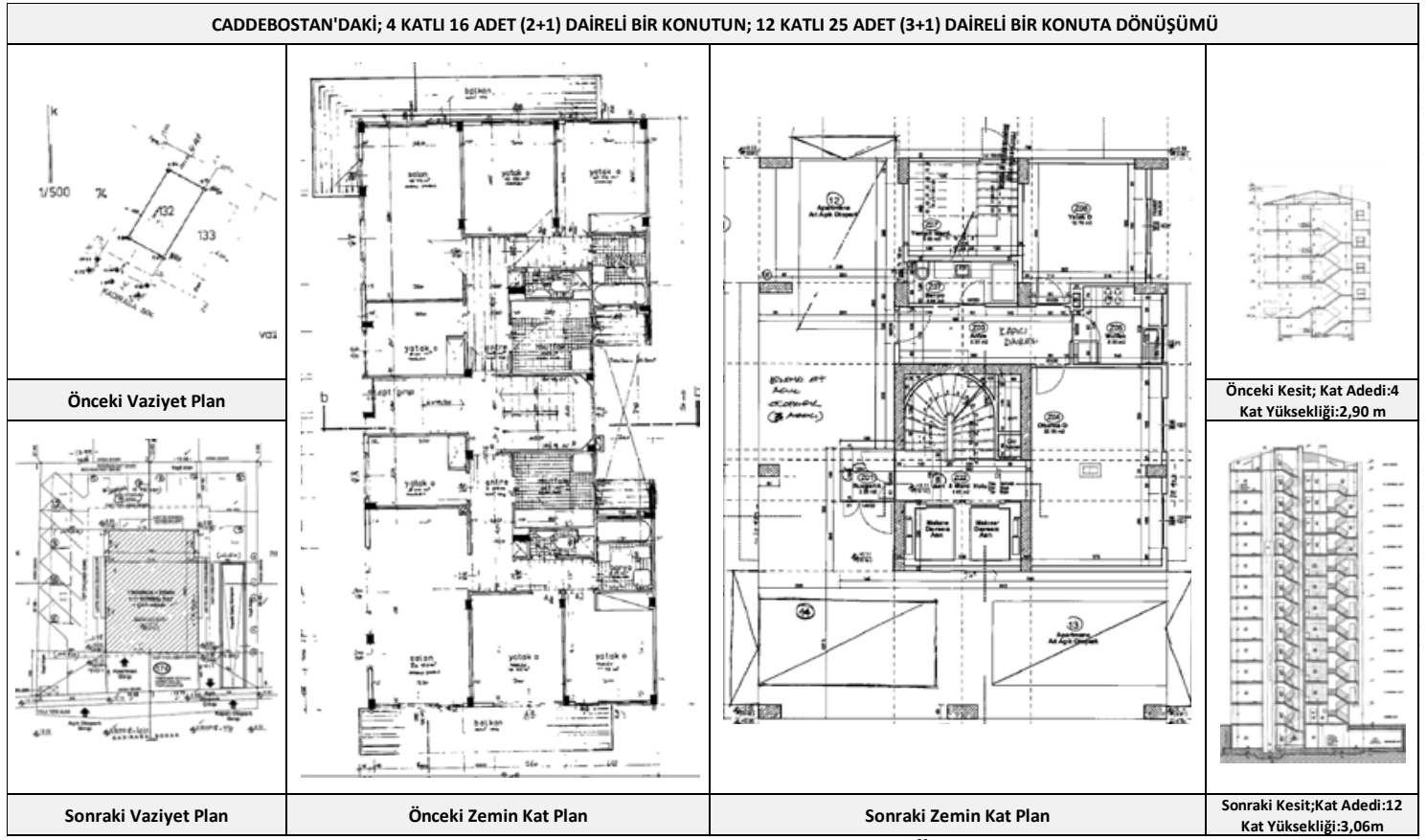

Şekil 23: Caddebostan'da Yenilenen Konutun Dönüşümden Önceki ve Sonraki Mimari Ruhsat Projesinden Görünümler

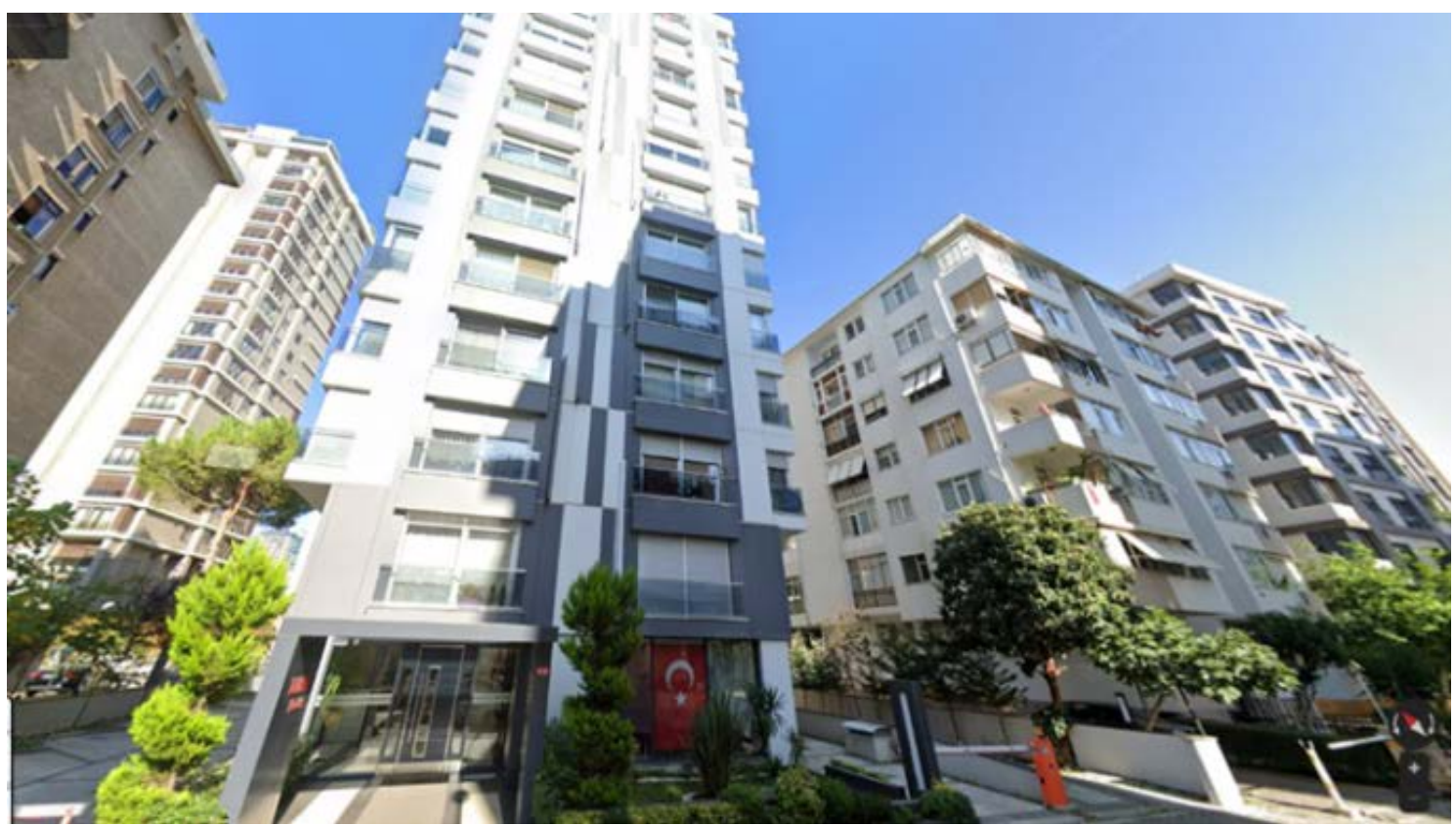

Şekil 24: Şekil 23’teki Konutun/Apartmanın Kapatılan Zemin Katının Görünümü 


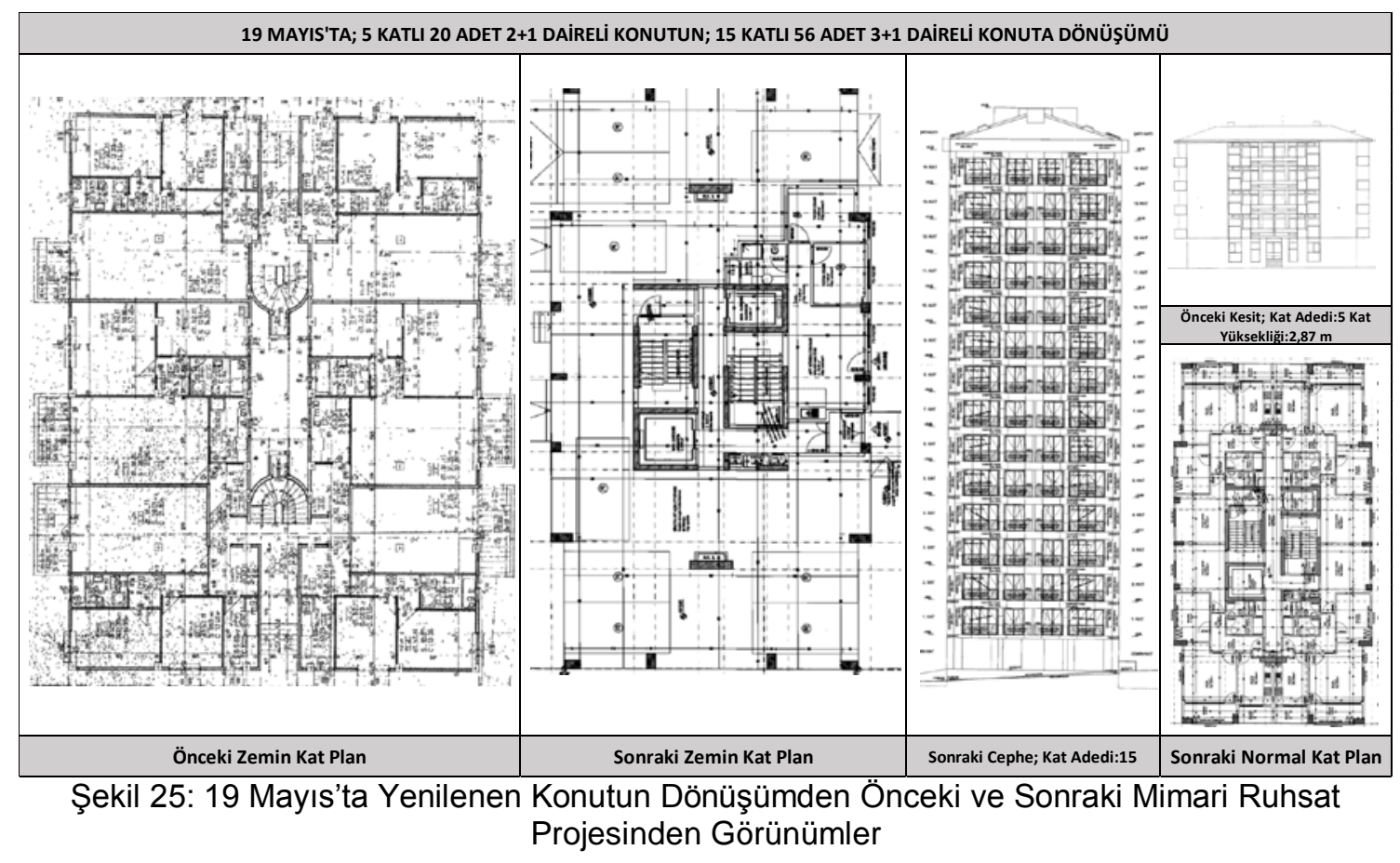

Artan kat sayısı ile birlikte ortaya çıkan yangın merdiveni intiyacı da kat planlarını kat holleri ve oda boyutları bakımından zorlamaktadır (Şekil 23, Şekil 25). Şekil 25'te her katta 4 dairesi olan (2+1) 5 katlı bir konut yapısının, 15 katlı yine her katta 4 dairesi olan bir konut kulesine dönüşümü görülmektedir.

\subsection{Normal Kat Planındaki Değişimin Yansımaları}

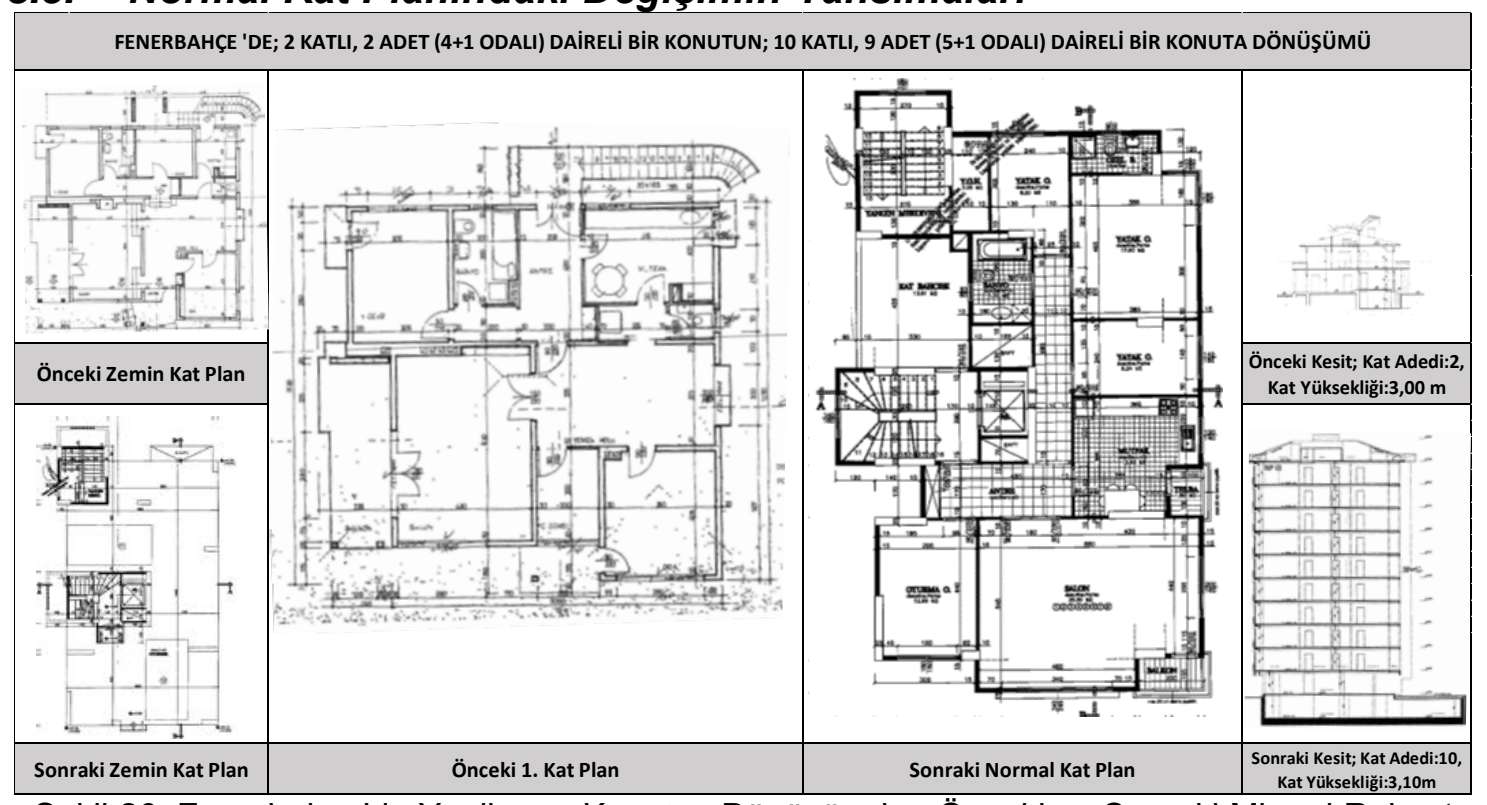

Şekil 26: Fenerbahçe'de Yenilenen Konutun Dönüşümden Önceki ve Sonraki Mimari Ruhsat Projesinden Görünümler

Özellikle az katlı ve az sayıda (katta tek) bağımsız bölüme sahip konutlardan çok katlı kulelere dönüşüm gerçekleştiğinde bağımsız bölüm/daire planlarının büyüklüguünde çok fazla değişim olmamaktadır (Şekil 26). Ancak katta 3-4 bağımsız bölümü olan bir 
konutun yine katta 4 bağımsız bölüme sahip bir konuta/apartmana dönüşümünde ise oda/mekan boyutlarının oldukça kısıtlı olarak tasarlandığı görülmektedir.

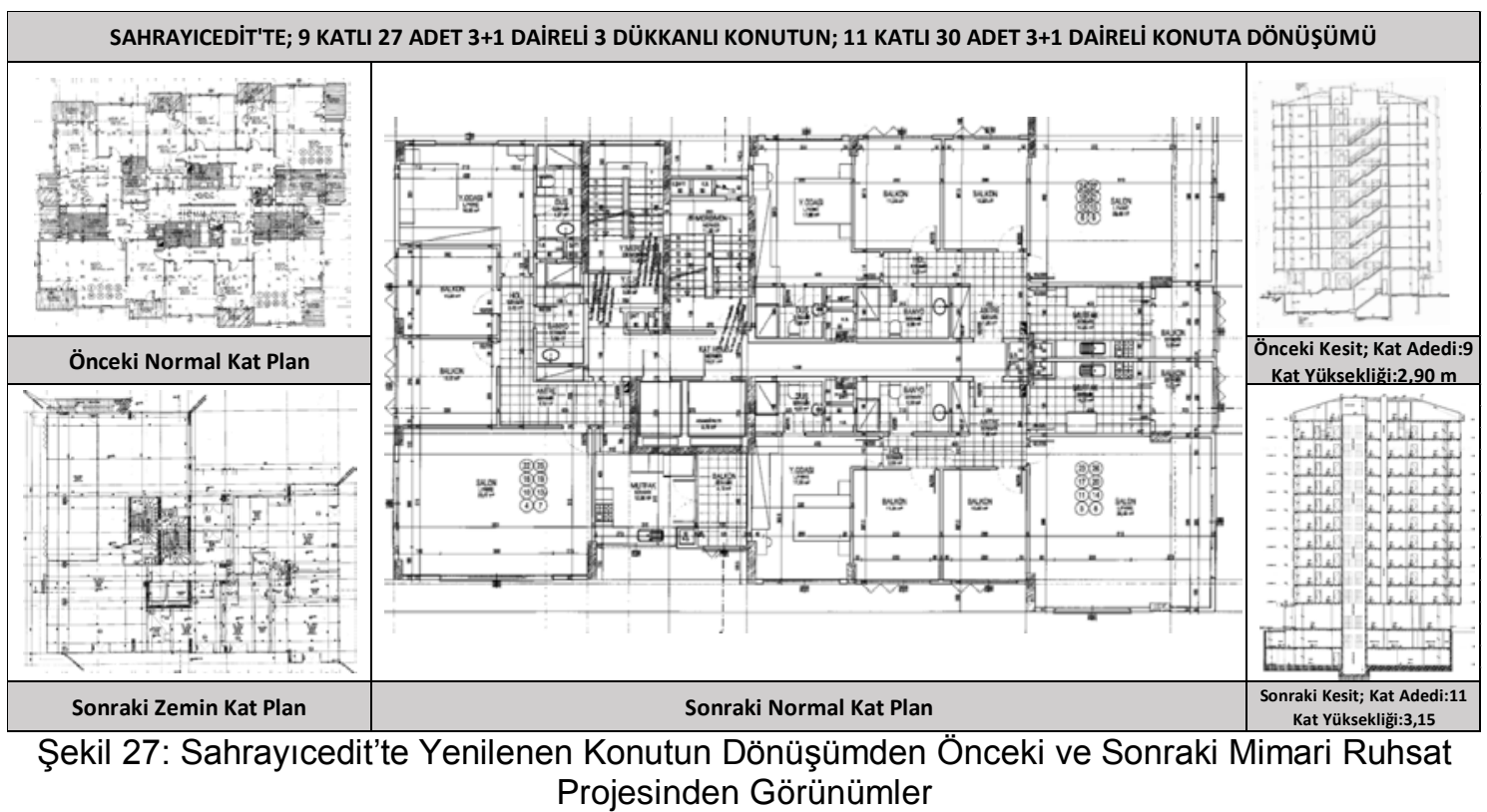

Dönüşen konutlarda çoğunlukla oda sayılarının çok fazla değişmediği görülmektedir. Fakat mutfakların ve giriş hollerinin daha büyük olmasının tercih edildiği anlaşılmaktadır. Katlar alanı hesabında spekülatif avantaj sağlamak için odaların balkon olarak gösterildiği örnekler dikkat çekmektedir (Şekil 27). Zorunlu olan yangın merdiveni düzenlemesinin kat planları planlamasını etkilediği görülmektedir. Kat holüne ve bağımsız bölüm odasına açılan iki tip kat planı çözümü ortaya çıkmaktadır. İyi ve kötü örnekler bir kez daha tasarımın ve bilginin ne kadar kıymetli olduğunu göstermektedir.

\subsection{Kesit ve Görünüşlerdeki Değişimin Yansımaları}

Kadıköy'de 1950'lerde 3 katlı, 1970-80'lerde 5 katlı ve 1990'larda 8-9 katlı olan konut yapılarının 25 katlara kadar yükseldiğini görmekteyiz. 11 örneği incelediğimizde; 2 kattan 12 kata, 4 kattan 22 kata, 5 kattan 15 kata, 6 kattan 12 kata evrilen örneklerin yanı sıra 8 kattan 9 kata dönüşen makul örnekler de görülmektedir. 15 kat sınırlaması getirilmiş olsa da plan notları ve imar yönetmeliğinin farklı yorumlanması nedeniyle farklı kat "imkânlarının" yaratıldığı düşünülmektedir. Şekil 28'de 4 kattan 22 kata, Şekil 29 'da ise 4 kattan 9 kata dönüşüm örnekleri görülmektedir.

Şekil 30'da ise 90'lı yıllarda çok katlı olarak inşa edilmiş $(Z+13)$ bir konut binasının 19 katlı çok daha büyük bir apartmana dönüşümü görülmektedir. Deprem riskine karşı çok daha büyük yeni bir yapı inşa etmek oldukça tartışmalı bir sonuç ortaya çıkarmıştır.

Yükselen konut kulelerinin cephe tasarımları dönemin, doluluk boşluk ve doku yaklaşımlarını yansıtmaktadır. Genellikle sıva cepheli olan eski binaların yerine, yeni binaların cephelerinde; tuğla, granit seramik, cam, pleksi, alüminyum profil, alüminyum kompozit vb. modern malzemelerin yaygın olarak kullanıldığı görülmektedir. 


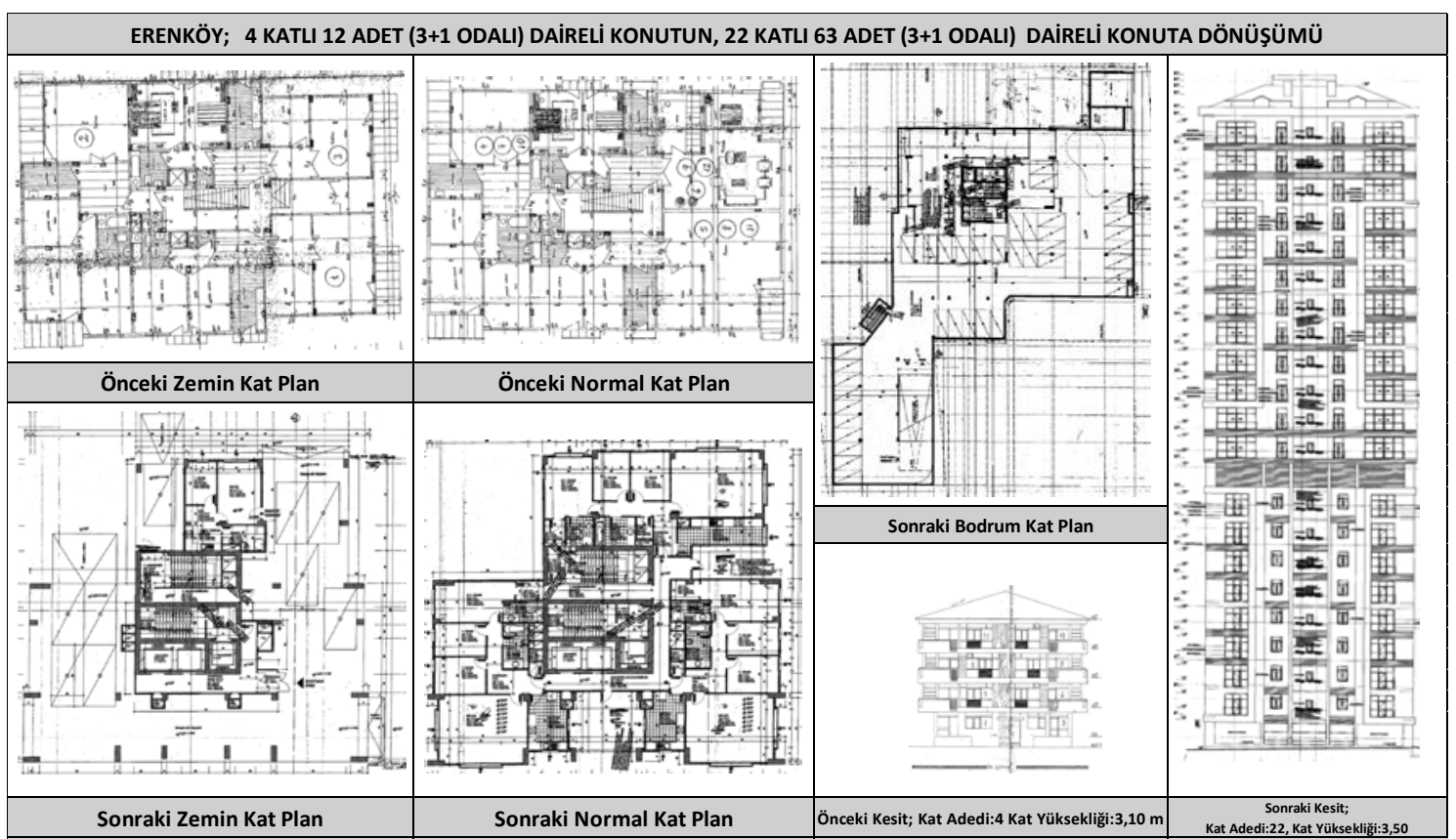

Şekil 28: Erenköy'de Yenilenen Konutun Dönüşümden Önceki ve Sonraki Mimari Ruhsat Projesinden Görünümler

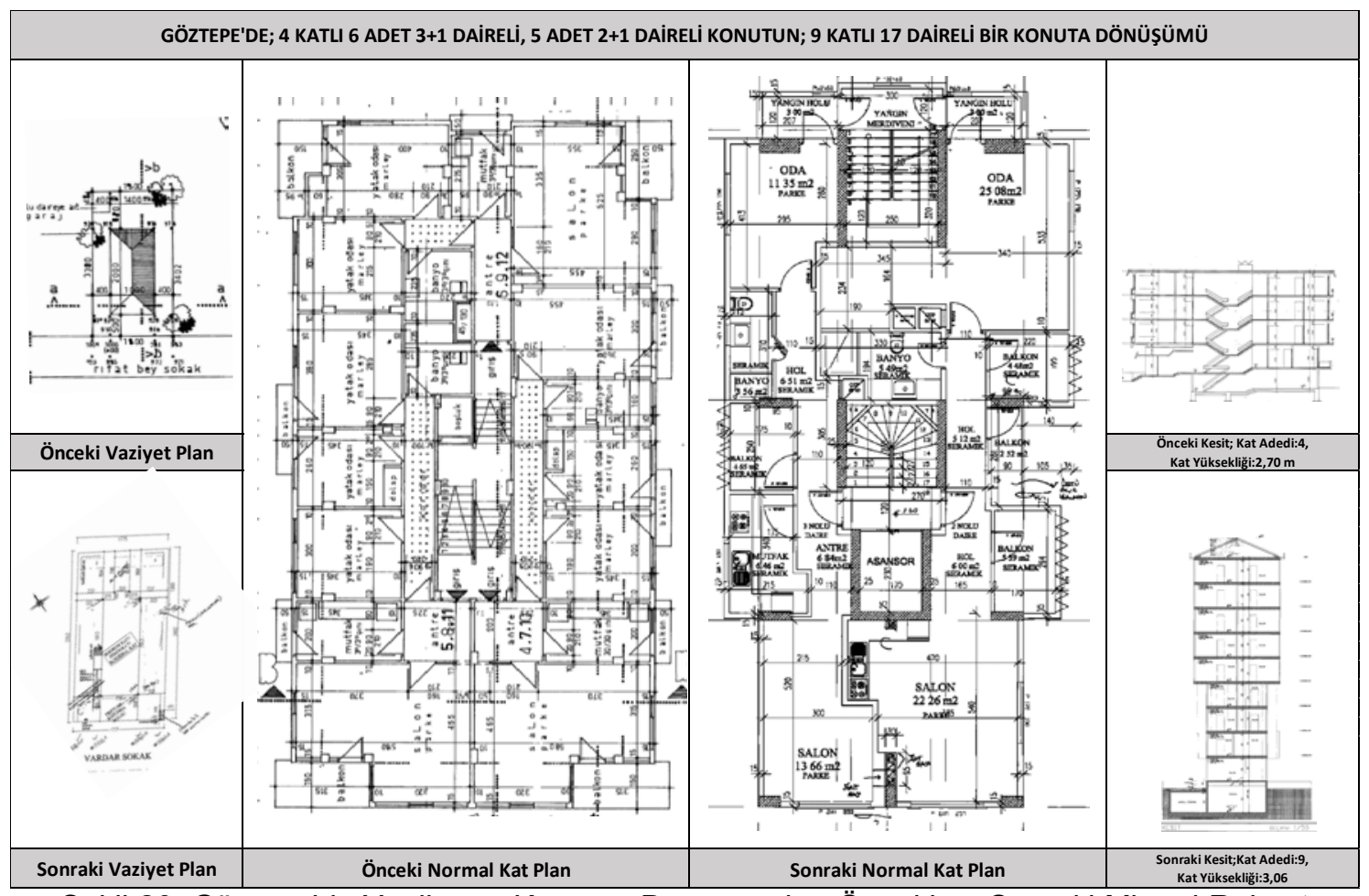

Şekil 29: Göztepe'de Yenilenen Konutun Dönüşümden Önceki ve Sonraki Mimari Ruhsat Projesinden Görünümler 


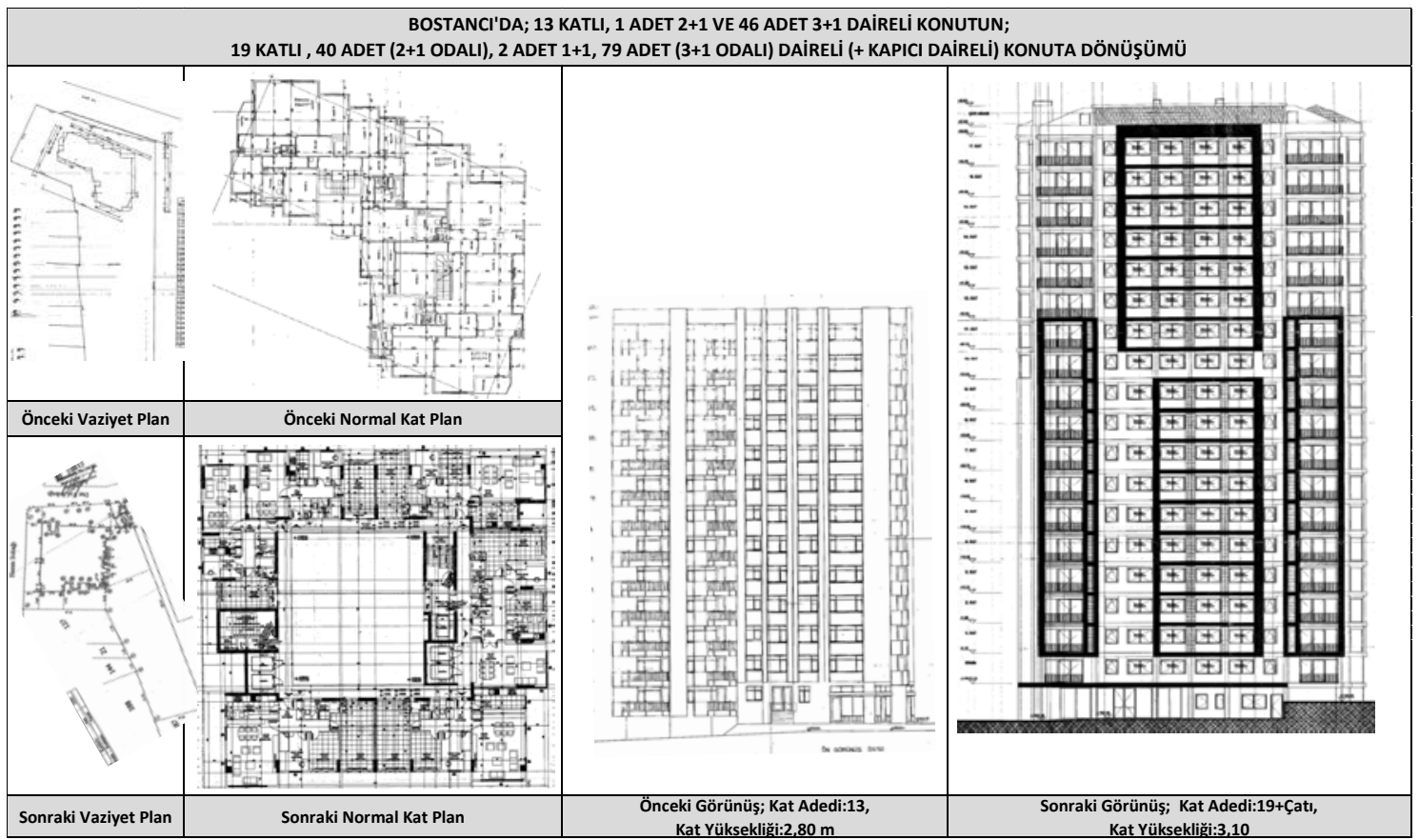

Şekil 30: Bostancı'da Yenilenen Konutun Dönüşümden Önceki ve Sonraki Mimari Ruhsat Projesinden Görünümler

\section{Değerlendirme ve Sonuç}

Bu çalışma konut politikalarının fiziksel ve hatta sosyal çevreyi oluşturmada doğrudan etkili olduğunu çarpıcı örneklerle göstermiştir. Ülkemizde (sosyal kırılmaların bir sonucu olarak) fiziksel çevrede oluşan kırılmaların özellikle, 1950 sonrası, 1980 sonrası ve 2000 sonrası yaşandığını söylemek yanlış olmayacaktır. Göçle ve nüfus artışıyla ortaya çıkan nitelikli konut ihtiyacının karşılanamamasında; gecekondulaşmayla başlayan, yoğun bir şekilde apartmanlaşmaya evrilen ve sonunda konutu ticari bir ürün olarak gören habitusun etkili olduğunu söylemek mümkündür. Bu habitusun oluşmasında en etkili faktör ise yönetim politikalarıdır. Devlet politikaları aynı zamanda sosyo-ekonomik koşullar ile döngüsel bir neden sonuç etkileşimi içindedir.

1950 sonrası, konut intiyacının karşılanmasında kat çıkma imkânı veren 1965 tarihli Kat Mülkiyeti Kanunu, 1982 yılında projeden satış imkânı veren yasal düzenlemeler ve imar afları, 1999 Marmara Depremi ve 2002 sonrası yapılan tüm yasal düzenlemeler ile; yap-sat (kamunun da aktörü olduğu) etkin ve yaygın bir konut sunum biçimi olmuştur. Herkes için edinilebilir nitelikli konut ve konut çevresi ihtiyacı ise büyümüş ancak karşılanamamıştır.

1999 Marmara Depremi'nden tam 13 yıl sonra 2012 yılında yürürlüğe giren "Afet Riski Altındaki Alanların Dönüştürülmesi Hakkında Kanun"nun amacı "fen ve sanat norm ve standartlarına uygun, sağlıklı ve güvenli yaşama çevrelerini teşkil etmek" şeklinde tanımlanmıştır. Ancak ilgili kanun bu amaca dair bir referans sunmamaktadır. TÜíK verileri bize 2002 yılından 2020'ye kadar, depreme karşı dayanıksız/riskli konutların yerine ikame edilebilecek 10 milyondan fazla yeni konutun inşa edildiğini göstermektedir (Çizelge 1). Eklenen bu büyük konut stokuna rağmen, halen 6,7 milyon konutun depreme dayanıksız olduğunu ve büyük İstanbul depremini beklediğini görmekteyiz (URL-20). 
Bununla birlikte kentsel dönüşüm sürecinin sadece Kadıköy gibi rant farkı yüksek bölgelerde hızla ilerlemesi dikkat çekicidir. Kentsel dönüşüm sürecinde Kadıköy'deki 30.000 konuttan, Fikirtepe'te 6.000'den fazla, Bağdat Caddesi ve çevresinde ise 4.000 'e yakın konut riskli yapı olarak tespit edilmiştir. Kadıköy gibi mevcut yapı kalitesi ve gelir seviyesi görece yüksek bir ilçede neredeyse İstanbul'un tüm ilçelerinden daha fazla riskli yapı tespitinin yapılması oldukça manidardır. Bu durum riskli yapı tescilinin doğruluğunu da sorgulanabilir hale getirmektedir.

Kadıköy'ün kentsel dönüşümde öncü olmasının sebepleri; mevcut fiziksel ve sosyal dokunun yükleniciye sunduğu rant farkı, ana ulaşım ağlarının Kadıköy'ün içinden ya da teğetinden geçmesi, yapı parsellerinin büyük ve derin olması, imar planında emsal (katlar alanı) katsayısının yüksek olması $(2,07 ; 4,14$ vb.), mal sahiplerinin demografik özellikleri şeklinde sıralanabilir.

Kentsel dönüşüm süreci sadece bir yenileme olarak görülmemelidir. Çünkü bu süreçte konut ve konut çevresi malesef "büyüyerek" şekil değiştirmektedir. Kentsel dönüşüm sürecinde riskli yapı sayısı 10.000'e yaklaşan Kadıköy'ün neredeyse 1/3'inin yenilendiğini ve kat sayısının ortalama \%100 arttığını söyleyebiliriz. Bu da 30.000 binalı Kadıköy'ün nüfusunun şimdilik 1,33 kat arttığını göstermektedir. Ayrıca bodrum katta parsellerin altının neredeyse tümüyle otopark (garaj) yapılabilmesi mevcut ağaçların çoğunu yok edecektir. Tarihi tescilli olmadığı takdirde gelecekte kentsel dokuda 2 katlı ve 4 katlı konut binalarını görmek mümkün olamayacaktır. Taban alanı katsayısının 0,35 olması yapılar arası mesafeyi korumak bakımından olumludur. Ancak yüksek emsal/katlar alanı değeri, 12-27 kat arasında yükselen kulelerle örülmüş yoğun bir doku oluşturmuştur. Dokunun değişimine rağmen değişmeyen ve aynı kalan kanalizasyon sistemlerinin ve yolların yetersiz kalacağı açıktır. Ayrıca artan nüfus yoğunluğuna karşılık (ilkokul vb.) kentsel donatı alanlarında hiçbir artış olamamaktadır. Yine, parsel ölçeğinde bile yüksek duvarlı güvenlikli site uygulamalarının yapılması sokakları insanla ilişkiden soyutlayarak daha güvensiz hale getirebilir. Bütün bu hususlar gelecekte bu bölgenin yaşayacağı fiziksel ve sosyal sorunların habercisidir (Şekil 31).

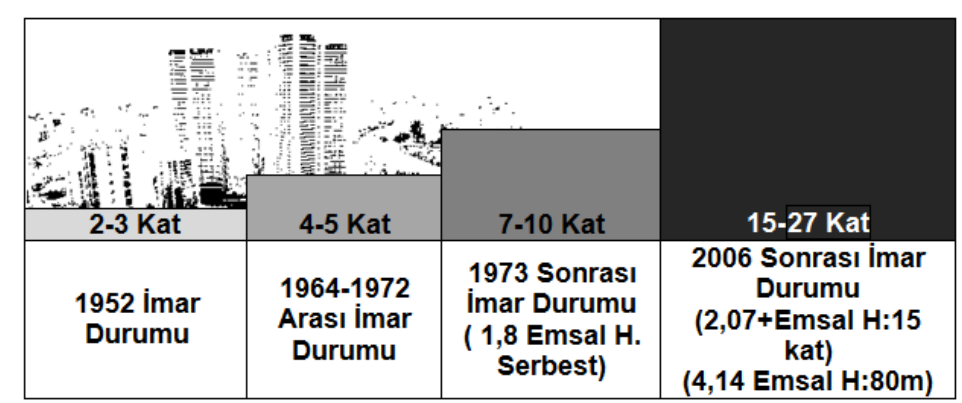

Şekil 31: Kadıköy İlçesi Tarihsel Süreç İçinde Konut İmar Haklarındaki Artış

Kentsel dönüşüm sürecinde Kadıköy'deki mimari yapı ruhsat projelerinde; zemin katların garaj, normal katlarda odaların balkon gösterildiği halde uygulamada oda olarak kapatılması gibi usulsüzlükler bize yapı denetim sürecinin de düzgün çalışmadığını göstermektedir. Bu da yenilenen binaların depreme dayanıklılık açısından da sorgulanabilir olduğu sonucunu beraberinde getirmektedir (Akyıldız, Konuralp, 2017, s.117).

Nitekim bu gibi yapılar nitelikli olma iddiasıyla yüksek gelir grubunu hedefleseler de ruhsat ve uygulama projelerinin farklı olması nedeniyle yapı ruhsatı süresi bitiminde (5 yıl) iskan ruhsatı alamadıkları için kaçak duruma düşmektedirler. Bu gibi yapılar için 23 
Nisan 2018'de kabul edilen "İmar Barışı" isimli yasa ile ülke genelinde 26 milyon yapı stokunun uygunsuz veya kaçak olan \%60'ının affedilmesinin yolu açılmıştır. Şekil 32'de 2019 yılında ekonomik nedenlerle 2002 seviyelerine yaklaşan konut yapı ruhsatı sayısına rağmen yükselen iskan ruhsatı sayısı da "imar barışı"nın bir sonucudur. Bu durum fiziksel çevrenin gelişimini doğrudan etkileyecek bir "sosyal kanıksama"nın da pekiştiricisi olmuştur.

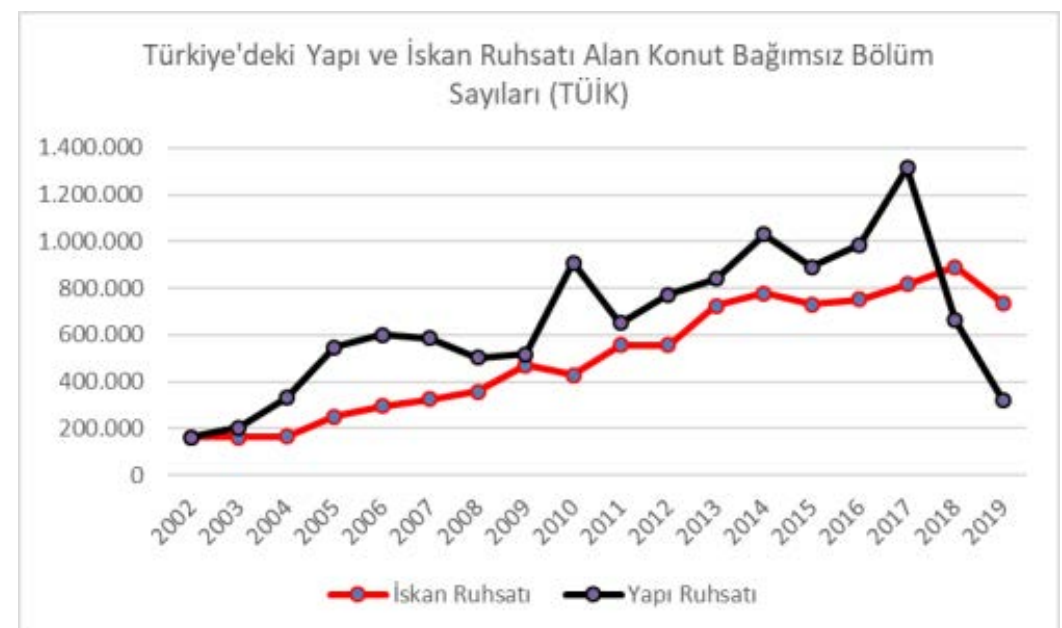

Şekil 32: Türkiye'deki Yapı ve İskan Ruhsatı Alan Konut Bağımsız Bölüm Sayıları (TÜİK, 2020)

Değeri sürekli yükselen bir yatırım aracına dönüşen konutun yapımındaki finansman bir şekilde karşılanabilmektedir. Yoksa bu denli konut arzıyla karşılaşamazdık. Hatta mevcut süreçte yenilenen evlerini satan eski mal sahiplerinin kent çeperlerinde yeni inşaat yatırımlarına yönelmesi İstanbul'da kuzeye büyüme baskısını da desteklemektedir.

Bu bağlamda kentlerin büyümesini yönetecek bir strateji geliştirilemediği görülmektedir. Mevcut sunum modelleri ve yürüyen mevzuatla daha çok konutu üretmek bizi nereye götürecektir? Bir 90 yıl sonra malzeme dayanım ömrünü tamamlayacak olan (çok malikli) bu dev betonarme bina kitlelerini nasıl dönüştüreceğimiz çok önemli bir sorun olarak karşımıza çıkacaktır.

Yaşam kalitesinin yüksek olduğu ülkelerde olduğu gibi; ülkemizde de nitelikli yaşam alanları yaratmayı hedefleyen yeni konut ve şehircilik politikaları üretilmelidir. Bilgiyi kullanarak ve paylaşarak, daha az maliyetle, yaşanabilir; binalar, mahalleler ve kentler yaratmak mümkündür (Design for London, 2010, s.119-121).

Yaşanası konut alanları sunabilmek için;

- Kullanıcının/insanın mutluluğunu için öncelikle konuta ve konut alanlarına yönelik; tasarım, ruhsat, yapım ve işletme sürecini içeren bütüncül standartlar ve düzenlemeler geliştirilmelidir. Kökleri 1960'lara ve 1980'lere dayanan imar mevzuatı da bu bağlamda geliştirilen standartlara/düzenlemelere tümüyle ve birbiriyle uyumlu bir şekilde yenilenmelidir. Dönüşmeyen mevzuat yaşam alanlarını da dönüştüremez.

- Yapı denetim mekanizması suiistimalleri azaltacak/yok edecek şekilde revize edilmelidir. Tasarım ve ruhsat sürecindeki denetleme ve onay mekanizmaları kullanıcı katılımı önceler şekilde güncellenmelidir. $\begin{array}{llccccc}\text { - Tüm idari ölçeklerde } & \text { yapı } & \text { stoklarına } & \text { dair; "riskli yapı", } \\ \text { "dönüşmüş/sağlamlaştırımış } & \text { yapı" } & \text { ve "riskli } & \text { olmayan yaşlı yapı" }\end{array}$ 
sınıflamalarında envanter çalışmaları tamamlanmalıdır. Bu çalışmalar güncel ve şeffaf olarak yürütülmelidir.

- Her ilde ve/veya ilçede üniversite ve kamu (Belediyeler ve Bakanlıklar) aktörlerinin aktif ve periyodik olarak görev alacağı sorun çözüm merkezleri kurulmalıdır. Bu merkezler bulundukları ilde ya da ilçede alanda ve süreçte karşılaşılan sorunların çözümünde halka danışarak karar almalıdır.

- Tasarım, yapım ve denetim sürecinde bilgiyi esas alan bir yönetim sistemini kurmaya ve uygulama yönelik olarak kararlı bir liderlik gösterilmelidir.

- Geliştirilen standart ve düzenlemelere göre "örnek yerleşim alanları" yeniden inşa edilmelidir.

\section{Kaynaklar}

Aydın Gök, Sıddıka Filiz, Konut Ediniminde Kullanıcı Kararlarını Etkileyen Faktörler; Istanbul İi Toplu Konut Projeleri Örneği, YL Tezi, GYTE, Mimarlık ABD, Kocaeli 2010.

Ayık, Uğurcan, Mekânsal ve Toplumsal Yansımalarıyla Türkiye'de Kentsel Dönüşüm Projelerine Coğrafi Bakış: Fikirtepe Örneği, ï̈ Sosyal Bilimler Enst., İstanbul 2014.

Akyıldız, Ahmet Tuğrul; Girgin, Konuralp, İstanbul'un Kentsel Dönüşümü Için Üretilen Binaların Deprem Güvenliklerinin Araştırılması, Dokuz Eylül Üniversitesi-Mühendislik Fakültesi Fen ve Mühendislik Dergisi, 2017, 19(55), s.100-121

Balamir, Murat, "Türkiye'de 'Apart Kent'lerin Oluşumu”, Tarihten Günümüze Anadolu'da Konut ve Yerleşme, Tarih Vakfı Yayını, İstanbul 1996, s. 335- 336.

Design for London, Published by London Development Agency, London 2010.

Dökmeci, Vedia; Boduroğlu, Hasan; Lale, Berköz Akkal, "Cities of Emlakbank", Creative Yayıncılık, İstanbul 1995.

Ertuğrul, Alidost, XIX. Yüzyılda Osmanlı'da Ortaya Çıkan Farklı Yapı Tipleri, Türkiye Araştırmaları Literatür Dergisi, İstanbul 2009, 7(13), s. 293-312.

Görgülü, T., Mimar.İst. “İstanbul'da Çeşitlenen Konut Üretim Biçimleri ve Değişen Konut Alışkanlıkları”, İstanbul 2003, s. 50-56,

Güvenç, Murat, Metropoliten Ölçekte Nüfus ve Yoğunluk Artışları; İstanbul (Kadıköy) Örneğinde Bir Ölçme ve Maliyet Çalışması, Yüksek Lisans Tezi, ODTÜ, Mimarlık Fak., Şehir Planlama Bölümü, Ankara 1979.

Harvey, David, "Ringt To The City", Debate and Developments, International Journal of Urban and Regional Research, 2003, 27(4), s.939-941

İBB,1/100.000 ÖLÇEKLİ ISTANBUL ÇEVRE DÜZENI PLANI RAPORU, İstanbul Büyükşehir Belediyesi İmar ve Şehircilik Daire Başkanlığı Şehir Planlama Müd., İstanbul 2009.

Kadıköy Belediyesi, Kadıköy Belediyesi Harita Müdürlüğü ve Riskli Yapı Tescil Bürosu Verileri; dwg harita, İstanbul 2020.

Keleş, Ruşen, Kentleşme Politikası, İmge Kitabevi, 5. Baskı, Ankara 2000. 
Özakbaş, Derya, "İstanbul Konut Mîmârîsinin 1923-1940 Yılları Arasındaki Gelişim Süreci", The Journal of Academic Social Science Studies International Journal of Social Science, Elazığ 2015, 40, s. 283-309.

Özüerken, Şule, “Kooperatifler ve Konut Üretimi”, Tarihten Günümüze Anadolu'da Konut ve Yerleşme, Tarih Vakfı Yayını, İstanbul 1996, s. 355-365.

Sey, Yıldız, "Cumhuriyet Döneminde Kent", 75 Yılda Değişen Kent ve Mimarlık, Türkiye İş Bankası-Tarih Vakfı Yayını, İstanbul, 1998, s.273-299.

Şenyapılı, Tansı, "Cumhuriyet'in 75. Yılı, Gecekondunun 50. Yılı", 75 Yılda Değişen Kent ve Mimarlık, Y. Sey (ed.), Türkiye İş Bankası-Tarih Vakfı Yayını, İstanbul 1998, s 301-316.

Tapan, Ahmet Mete, “Toplu Konut ve Türkiye'deki Gelişimi”, Tarihten Günümüze Anadolu'da Konut Ve Yerleşme, Tarih Vakfı Yayını, İstanbul 1998, s. 366-378.

Tekeli, İlhan, "Türkiye'de Konut Sunumunun Davranışsal Nitelikleri ve Konut Kesiminde Bunalım”, Konut81, Kent-Koop. Yayını, Ankara 1982, s 57-101.

Tekeli, İlhan, Türkiye'nin Konut Tarihine Konut Sunum Biçimleri Kavramını Kullanarak Yaklaşmak, Konut Araştırmaları Sempozyumu, Ankara 2011, s. 283-297.

Toprak, Zerrin, “Kent Yönetimi ve Politikası”, Anadolu Matbaacılık, İzmir 2001.

Tosun, Elif Karakurt, “Türkiye'de Konut İhtiyacı ve Konut Finansmanı”, Paradoks Dergisi, 2 (2), Bursa 2006.

Yavuz, Mehmet, Hellmuth Cuno, Anadolu-Bağdat Demiryollarının Yapımında Görev Alan Mimar ve Mühendisler, Ankara 2008, s.299-311.

\section{İnternet Kaynakları}

URL-1. https://biruni.tuik.gov.tr/yapiizin/giris.zul (Erişim:10.10.2020)

URL-2. https://en.wikipedia.org/wiki/Kad\%C4\%B1k\%C3\%B6y (Erişim:25.05.2020)

URL-3. https://www.slideshare.net/KadikoyBelediye/kadkoy-planlar (Erişim:25.05.2020)

URL-4. www.kadikoy.bel.tr/Kadikoy/Cografi-Konum (Erişim:30.04.2020)

URL-5. https://anlat.kadikoy.bel.tr/kbpanel/Uploads/Files/Merkez\%20Kad \%C4\%B1k\%C3\%B6y.pdf (Erişim:10.07.2020)

URL-5. https://www.arkitera.com/haber/kentsel-donusum-arifesinde-bagdat-caddesineyolculuk/ (Erişim:15.05.2020)

URL-6. http://sehirharitasi.ibb.gov.tr/ (Erişim:11.04.2020)

URL-7. http://www.berkolon.com/projeler/tamamlanan-projeler/1 (Erişim:15.05.2020)

URL-8.http://www.arkitera.com/haber/12480/gecmisin-modern-mimarisi---1--kadikoy (Erişim:15.05.2020) 
URL-9.http://img-3.onedio.com/img/719/bound/2r0/52cb29967a7bb086740000ab.webp (Erişim:20.05.2020)

URL-10. http://gazetearsivi.milliyet.com.tr/Stfa/ (Erişim:10.07.2020)

URL-11.www.csb.gov.tr/gm/altyapi/index. php?Sayfa=sayfa\&Tur=webmenu\&ld=8291 (Erişim:17.05.2020)

URL-12.http://www.csb.gov.tr/gm/altyapi/index.php?Sayfa=sayfahtml\&ld=2091 (Erişim:21.05.2020)

URL-13.http://www.haberturk.com/gundem/haber/1367733-bakan-ozhasekiden-kritikdeprem-uyarisi (Erişim:22.05.2020)

URL-14.http://www.cnnturk.com/ekonomi/on-odemeli-konut-satisinda-yeni duzenleme?page $=5$ (Erişim:20.05.2020)

URL-15. http://www.atasav.org/index.php?sid=18(Erişim:11.04.2020)

URL-16.https://www.slideshare.net/KadikoyBelediye/kadkoy-planlar(Erişim:11.04.2020) URL-17.http://www.radikal.com.tr/ekonomi/kentsel-donusum-zammi-1148686/ (Erişim:19.05.2020)

URL-18.http://www.milliyetemlak.com/dergi/fikirtepede-metrekare-10-bin-dolarolacak/(Erişim:20.05.2020)

URL-19.http://www.gazetekadikoy.com.tr/gundem/nuhoglu-kentsel-donusum-insanicin-yapilmali-h10136.html (Erişim:25.05.2020)

URL-20.https://www.ntv.com.tr/emlak/bakan-kurum-yenilenmesi-gereken-6-7-milyonkonut-var,ITEFYh1rPUKclOmXgMkNeQ (Erişim:15.05.2020) 